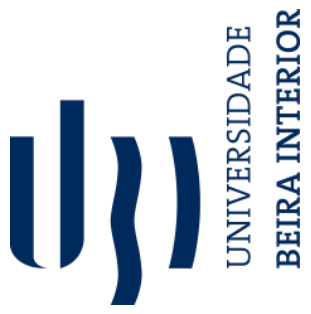

\section{Mental Health, Resilience and HIV in Older Gay and Bisexual Men}

\author{
Inês Catarina Monteiro Batista
}

Dissertação para obtenção do Grau de Mestre em

Psicologia Clínica e da Saúde

( $2^{\circ}$ ciclo de estudos)

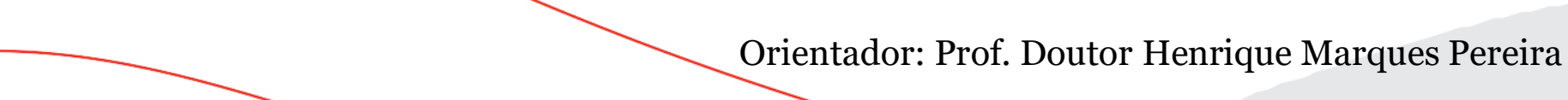

Orientador: Prof. Doutor Henrique Marques Pereira 
Mental Health, Resilience and HIV in Older Gay and Bisexual Men 


\section{Dedicatória}

Ao meu tio e ao meu avô. Sei que me aplaudem onde quer que estejam. 
Mental Health, Resilience and HIV in Older Gay and Bisexual Men 


\section{Agradecimentos}

Em primeiro lugar, agradecer ao Prof. Doutor Henrique Pereira enquanto orientador da presente Dissertação, por toda a disponibilidade, atenção e paciência no decorrer de todo o processo e por me ter sempre incentivado a fazer mais e melhor, superando as expectativas que tinha de mim própria.

Aos meus pais, pelos sacrifícios que fizeram e fazem todos os dias por mim, para que eu possa ter um futuro risonho. Prometo nunca vos desiludir.

À minha irmã, por ser uma fonte inesgotável de motivação.

Ao Miguel, por estar presente durante toda a minha caminhada, pelas palavras de carinho e de motivação, por nunca me deixar desistir. Por mesmo estando longe, estar sempre tão perto.

À minha família, por todo o apoio que me deram e continuarão a dar.

Ao meu Squad - Bárbara, Mariana e Marina - por serem o meu porto de abrigo em todos os momentos. Para sempre.

Às minhas madrinhas, por todos os conselhos e por serem a minha bússola nesta aventura.

Às minhas afilhadas, por todos os momentos que partilhámos, por todos os sorrisos e por confiarem na pessoa que sou.

Aos meus amigos, por estarem presente nos momentos que me trouxeram até aqui.

À minha EncantaTuna, por me ter ajudado a crescer durante todo o meu percurso e por me fazer ter algo ao qual posso sempre regressar.

E, por último, à Cidade Neve e à Universidade da Beira Interior, por terem colocado no meu caminho tantas experiências, momentos e pessoas incríveis. Nunca serão esquecidas. 
Mental Health, Resilience and HIV in Older Gay and Bisexual Men 


\section{Introdução}

A presente dissertação integra o projeto “(h)ARPA - Adjustment, Risk and Protective Factors in LGBT+ Older Adults", conduzido em Portugal e em Espanha, cujo objetivo é investigar os diferentes aspetos do bem-estar psicológico e físico de pessoas LGBT+. Esta será apresentada em formato de artigo científico, em inglês. Como tal, terá inicialmente um resumo alargado em português, e, de seguida, o capítulo que corresponde à investigação em si, em inglês.

O objetivo deste estudo é avaliar as disparidades nos níveis de saúde mental entre indivíduos do sexo masculino, gays e bissexuais mais velhos, de acordo com o seu diagnóstico de VIH. Como indicadores de saúde mental apresentam-se: a ansiedade, a depressão, a autoestima e a resiliência de uma amostra de homens gays e bissexuais, mais velhos (+ de 50 anos), comparando esses mesmos níveis entre os homens gays e bissexuais, mais velhos, portadores de VIH com os homens gays e bissexuais, mais velhos, não portadores; e, determinar o efeito preditor da resiliência e da autoestima na saúde mental dos homens gays e bissexuais mais velhos. Este pode ser classificado como um estudo quantitativo, descritivo, uma vez que permite a identificação, o registo e a análise de variáveis, descrevendo como estas se comportam na amostra; um estudo comparativo, na medida em que se pretende comparar como se comportam as variáveis entre dois grupos distintos; preditivo, na medida em que se estabelecem relações preditivas entre variáveis; e, um estudo transversal, já que mede a frequência de manifestação de um acontecimento numa população, num determinado momento.

Para recolha dos dados foram utilizadas medidas como a Escala de Autoestima de Rosenberg, o Brief Symptom Inventory (BSI-18) e a Escala de Resiliência de ConnorDavidson, com um total de 201 participantes, isto para além do questionário sociodemográfico. As idades dos participantes situam-se entre os 50 e os 79 anos, sendo que a média de idades é 58.85. Mais de metade dos participantes identificam-se como gays (80.6\%) e 13.9\% como bissexuais, sendo que 16.9\% têm diagnóstico positivo de VIH.

Para além do artigo científico, a presente dissertação inclui, ainda, um apêndice teórico, no qual são explorados de forma mais detalhada todos os conceitos abordados, de forma a aprofundar e consolidar os fundamentos teóricos presentes no artigo, assim como anexos com publicações que estão na base do presente estudo. 
Mental Health, Resilience and HIV in Older Gay and Bisexual Men 


\section{Resumo Alargado}

Os problemas de saúde mental são mais prevalentes na comunidade LGBT, quando esta é comparada com a comunidade heterossexual (King et al., 2008), na medida em que a perceção da discriminação e do estigma pode ter efeitos negativos elevados no que diz respeito à saúde mental (Pascoe \& Richman, 2009). No caso particular dos indivíduos LGBT mais velhos, estes têm de ultrapassar problemas idênticos a qualquer idoso heterossexual, sendo que ambas as comunidades se preocupam com a manutenção da independência, das finanças, da segurança, do apoio social, da saúde e do combate à solidão e isolamento (MetLife, 2010 citado por Gardner et al., 2014). Contudo, aos indivíduos LGBT mais velhos acrescem as preocupações e obstáculos que advêm das experiências de estigmatização social e discriminação ao longo de toda a sua vida (Gardner et al., 2014), vivendo com o legado e a experiência contemporânea de homofobia, associados à tensão produzida pelo próprio processo de envelhecimento (Richards, 2011 citado por Pereira et al., 2018). Existe, ademais, uma associação positiva entre a discriminação interpessoal e os maus resultados em saúde física e mental entre minorias sexuais, abrangendo o risco e infeção pelo VIH (Lyons, Pitts, \& Grierson, 2012; Ayala et al. 2012; Beyrer et al. 2012; Wolitski \& Fenton, 2011 citados por Pereira \& Costa, 2016). Desta forma, e tendo por base o que foi explanado anteriormente, assim como a restante pesquisa bibliográfica realizada, este estudo pretende avaliar as disparidades que existem nos níveis de saúde mental entre indivíduos do sexo masculino, gays e bissexuais, mais velhos, de acordo com o seu diagnóstico de VIH. Assim, espera-se preencher um vazio que existe em Portugal acerca desta área de prevenção e intervenção, pretendendo contribuir para o desenvolvimento de programas em relação à saúde mental nas comunidades gays e bissexuais durante o processo de envelhecimento destes indivíduos.

Os dados da amostra foram recolhidos através de um site construído para o efeito onde foram esclarecidos os objetivos da investigação e todas as questões éticas que lhe estão associadas, garantindo as instruções do mesmo. Os critérios de inclusão da amostra consistiam em ser do sexo masculino, identificar-se como gay ou bissexual e ter uma idade superior a 50 anos. Deste modo, foram reunidas respostas de um total de 201 participantes, sendo que $80.6 \%$ dos homens se identificou como homossexual e $13.9 \%$ como bissexual, em que $16.9 \%$ dos indivíduos têm diagnóstico positivo de VIH.

Os participantes responderam à Escala de Autoestima de Rosenberg, de forma a averiguar os níveis de autoestima dos sujeitos; ao BSI-18, avaliando a psicossintomatologia experienciada pelo indivíduo na última semana, através de três 
subescalas - somatização, depressão e ansiedade; e, por último, à CDRISC-10, através da qual se estimam os valores de resiliência do indivíduo. Todas as medidas apresentaram medidas de validade interna adequadas, .85 pontos, .93 pontos, .91 pontos e .86 pontos, relativamente à Escala de Autoestima de Rosenberg, ao BSI-18 e suas subescalas depressão e ansiedade, respetivamente.

Foram, ainda, realizados Testes $\mathrm{t}$ para amostras independentes, sendo que estes demonstraram que os homens bissexuais mais velhos da amostra apresentam níveis mais elevados de autoestima (média $=3.55$ ) em comparação com os homens mais velhos bissexuais (média = .43); que os homens gays mais velhos demonstram níveis superiores de depressão (média $=.81$ ) quando comparados com os homens bissexuais mais velhos (média $=.70$ ); e que os homens bissexuais mais velhos revelam níveis de resiliência superiores (média $=4.40$ ) em comparação com os homens gays mais velhos (média = 4.06). O teste de correlação de Pearson permitiu observar que a autoestima se encontra negativamente correlacionada tanto com a depressão $(r=-.539)$ como com a ansiedade ( $\mathrm{r}$ $=-.476)$ e positivamente correlacionada com a resiliência $(r=.517)$; a depressão se encontra negativamente correlacionada com a resiliência $(r=-.440)$ e positivamente correlacionada com a ansiedade $(r=.805)$; e que a ansiedade se encontra negativamente correlacionada com a resiliência $(\mathrm{r}=-$-.338). Os modelos de regressão linear múltipla demonstram explicar 33\% da variação geral dos sintomas depressivos e 25\% da variação dos sintomas ansiosos, sendo que níveis mais baixos de autoestima e resiliência são preditores de sintomas depressivos, assim como níveis inferiores de autoestima são preditores de sintomas ansiosos.

O estudo em questão pretendeu, assim, explorar a relação existente entre a saúde mental, a orientação sexual e o diagnóstico de VIH, mostrando-se como um estudo pioneiro em Portugal acerca desta temática. As principais conclusões evidenciam a importância de trabalhar com esta população específica, contribuindo para a melhoria do bem-estar e da qualidade de vida dos homens mais velhos gays e bissexuais com e sem diagnóstico de VIH.

\section{Palavras-chave}

Saúde mental; ansiedade; depressão; autoestima; resiliência; gay; bissexual; VIH 
Mental Health, Resilience and HIV in Older Gay and Bisexual Men 
Mental Health, Resilience and HIV in Older Gay and Bisexual Men 


\section{Índice}

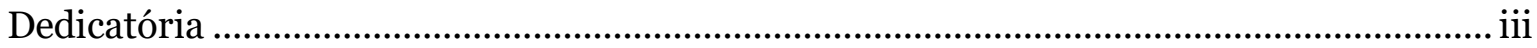

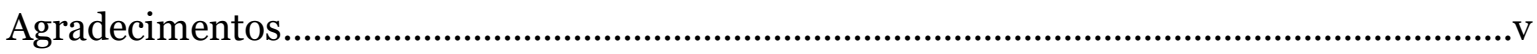

Introdução .......................................................................................................................... vii

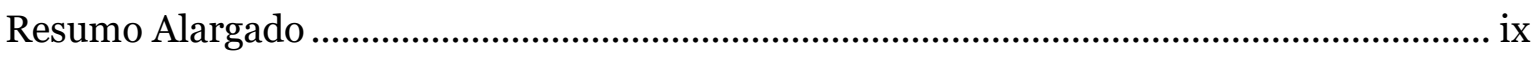

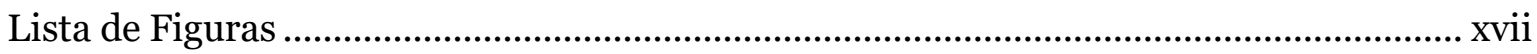

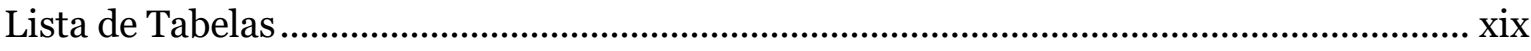

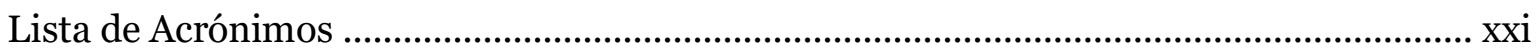

Capítulo 1: Mental Health, Resilience and HIV in Older Gay and Bisexual Men................. 23

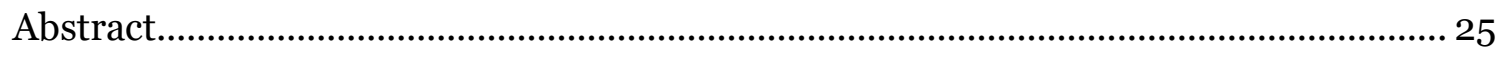

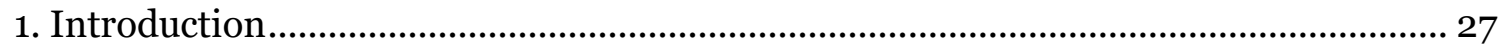

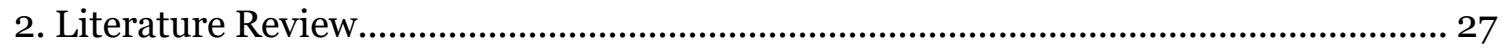

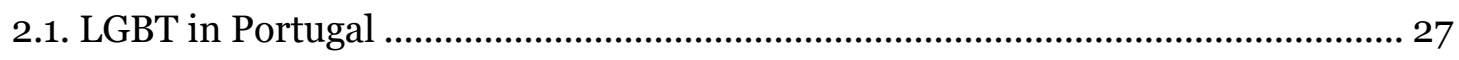

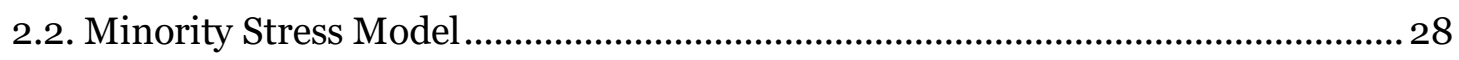

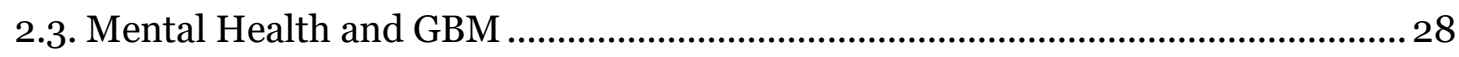

2.4. GBM and the Aging Process................................................................................... 29

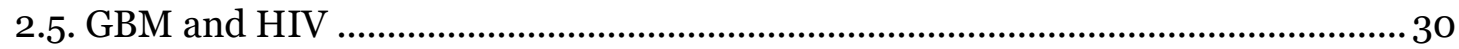

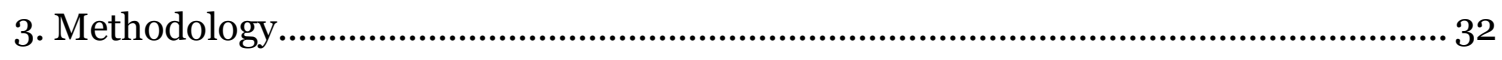

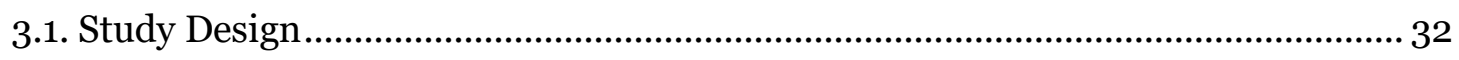

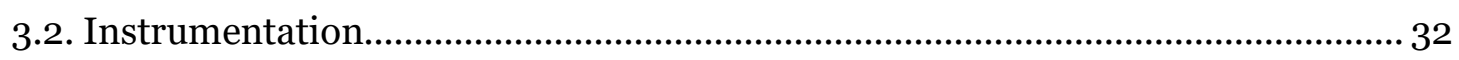

3.3. Study Analytic Methods ......................................................................................... 33

3.4. Sample Description ................................................................................................ 34

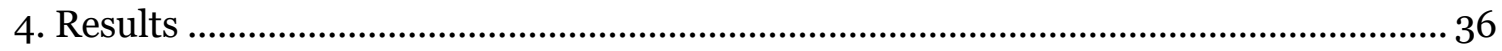

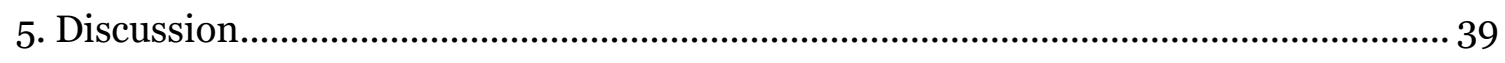

5.1. Mental Health and GBM..................................................................................... 39

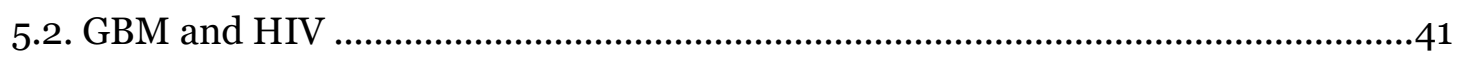

6. Limitations and Future Directions ……….....................................................................41

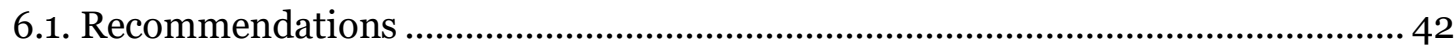

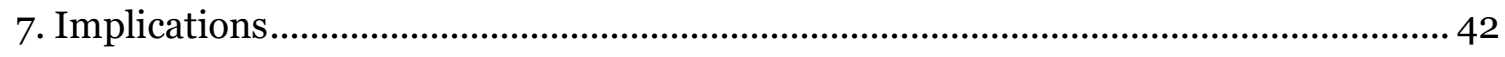




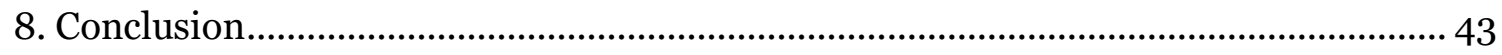

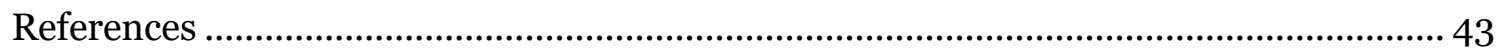

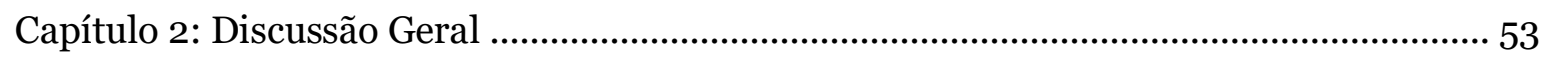

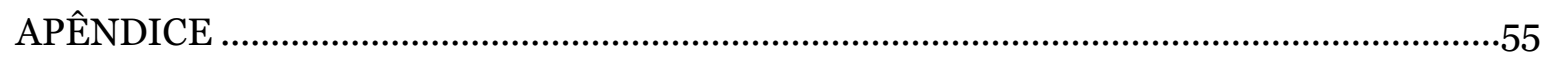

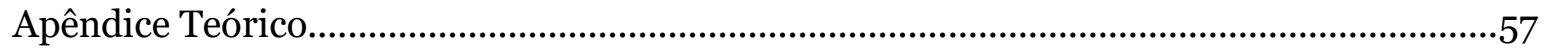

1. Saúde Mental .........................................................................................................

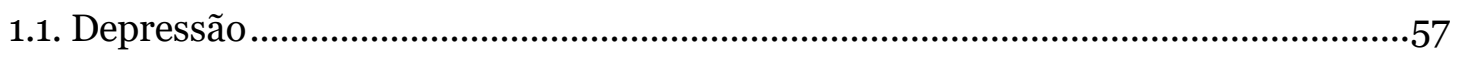

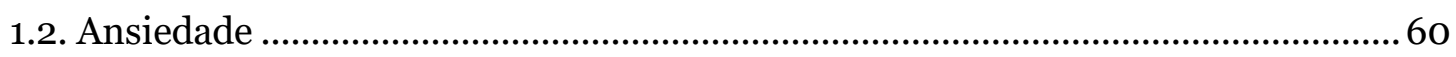

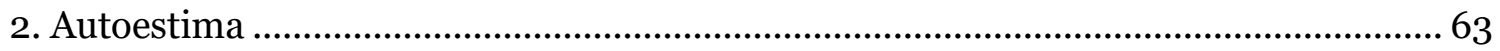

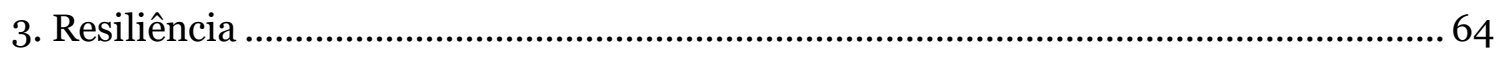

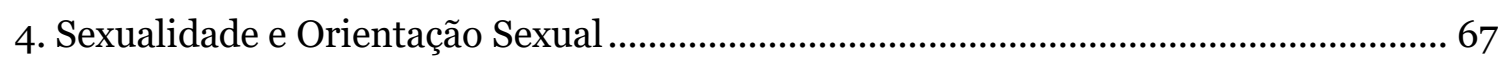

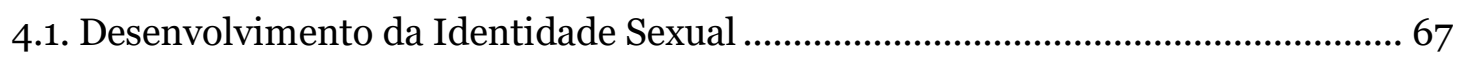

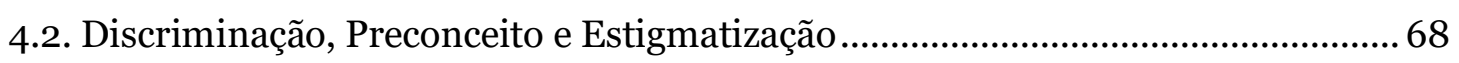

4.3. Modelo de Stress de Minorias ...................................................................................... 70

4.4. O Processo de Envelhecimento e Orientação Sexual ............................................... 72

5. Vírus da Imunodeficiência Humana................................................................................. 74

5.1. VIH, Processo de Envelhecimento e Orientação Sexual ...........................................75

6. Saúde Mental na Comunidade LGBT com VIH ........................................................... 76

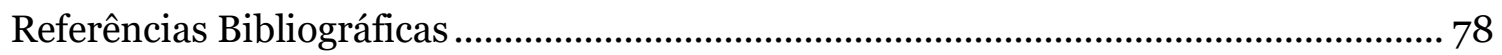


Mental Health, Resilience and HIV in Older Gay and Bisexual Men 
Mental Health, Resilience and HIV in Older Gay and Bisexual Men 
Mental Health, Resilience and HIV in Older Gay and Bisexual Men

\section{Lista de Figuras}

Figura 1. - Modelo de stress de minorias 
Mental Health, Resilience and HIV in Older Gay and Bisexual Men 


\section{Lista de Tabelas}

Tabela 1. - Sociodemographic data of the sample

Tabela 2. - Results for levels of self-esteem, depression, anxiety and resilience

Tabela 3. - T test for independent samples - Sexual orientation and HIV

Tabela 4. - Results for the levels of correlation between variables

Tabela 5. - Linear regression model 
Mental Health, Resilience and HIV in Older Gay and Bisexual Men 


\section{Lista de Acrónimos}

LGBT Lesbian, Gay, Bisexual and Transgender

GBM Gay and Bisexual Men

LGB Lesbian, Gay and Bisexual

HIV Human Immunodeficiency Virus

MSM Men who have Sex with Men

BSI-18 Brief Symptom Inventory 18

CDRISC-10 Connor-Davidson Resilience Scale 10

OMS Organização Mundial de Sáude

DSM-5

Manual de Diagnóstico e Estatístico das Perturbações Mentais - $5^{\mathrm{a}}$

Edição

IACLIDE Inventário de Avaliação Clínica da Depressão

CES-D Center for Epidemiologic Studies Depression Scale

BDI-II Beck Depression Inventory - II

SCL-90-R Symptom Checklist-90-R

EADS $\quad$ Escalas de Ansiedade, Depressão e Stress

GSI Índice de Gravidade Global

PSDI Índice de Sintomas Positivos

PST Número de Sintomas Positivos

APA American Psychological Association

DSM - III

Manual de Diagnóstico e Estatístico das Perturbações Mentais $-3^{\mathrm{a}}$ Edição 
Mental Health, Resilience and HIV in Older Gay and Bisexual Men 


\section{Capítulo 1: Mental Health, Resilience and HIV in Older Gay and Bisexual Men}

Este capítulo é escrito com base nas seguintes atividades científicas:

- Publicações

Batista, I., \& Pereira, H. (2020). Mental health, resilience and HIV in older gay and bisexual men. Educational Gerontology. https://doi.org/10.1080/03601277.2020.1785673

Batista, I. C. \& Pereira, H. (2020). Disparidades na saúde mental entre homens gays e bissexuais mais velhos com e sem diagnóstico de VIH.Psicologia, Saúde \& Doenças,21(1), 53-61 http://dx.doi.org/10.15309/20psd210109

Batista, I., \& Pereira, H. (2020). Disparidades na saúde mental entre homens gays e bissexuais mais velhos com e sem diagnóstico de VIH. Psicologia, Saúde \& Doenças, 21 (Sup), 189.

- Comunicações

Batista, I., \& Pereira, H. (30 de janeiro de 2020). Disparidades na saúde mental entre homens gays e bissexuais mais velhos com e sem diagnóstico de VIH. Comunicação apresentada no $13^{\circ}$ Congresso Nacional de Psicologia da Saúde (Sociedade Portuguesa de Psicologia da Saúde), Covilhã.

- Prémios

Prémio Científico de Jovem Investigador de Mérito no $13^{\circ}$ Congresso Nacional de Psicologia da Saúde (1 de fevereiro de 2020, Sociedade Portuguesa de Psicologia da Saúde) que decorreu na Universidade da Beira Interior, com o trabalho "Disparidades na Saúde Mental entre homens gays ebissexuais com e sem diagnóstico de VIH". 
Mental Health, Resilience and HIV in Older Gay and Bisexual Men 


\begin{abstract}
The present study seeks to evaluate mental health disparities among older gay and bisexual men, based upon their HIV status. The study can be classified as a quantitative, descriptive, comparative and cross-sectional study. Responses were collected from a total of 201 men, with $16.9 \%$ being HIV positive, 80.6\% identifying as homosexual and $13.9 \%$ identifying as bisexual. Participants responded to the Rosenberg Self-Esteem Scale, the BSI-18 and the CDRISC-10. The sample collected revealed moderate levels of self-esteem, depression and anxiety that were below the average observed among the general population, as well as higher than expected levels of resilience. Older bisexual men showed higher levels of self-esteem and resilience in comparison with older homosexual men, while older gay men showed higher levels of depression when compared to older bisexual men. Self-esteem was negatively correlated with both depression and anxiety, while being positively correlated with resilience. In contrast, depression was negatively correlated with resilience and, conversely, positively correlated with anxiety. Furthermore, anxiety was negatively correlated with resilience. Multiple linear regression models explain $33 \%$ of the general variation of depressive symptoms and $25 \%$ of the variation of symptoms of anxiety. Regarding comparisons based upon HIV status, no statistically significant differences were found between HIV-positive and HIV-negative men.
\end{abstract}

\title{
Keywords
}

Mental health; anxiety; depression; self-esteem; resilience; gay; bisexual; HIV. 
Mental Health, Resilience and HIV in Older Gay and Bisexual Men 


\section{Introduction}

Nowadays the community that integrates lesbian, gay, bisexual and transgender (LGBT) people has more and more visibility, and as such, as it is a rising sexual minority, its study begins to have more and more relevance. However, this community still does not have due recognition in terms of its representativeness and, thus, the coming-out process of these subjects can have very negative consequences for their mental health, which may result in the development of depressive or anxious symptoms, adverse to the individual's life. The LGBT community can be subdivided into several groups, namely one being gay or bisexual men (GBM), who are particularly sensitive to the development of sexually transmitted diseases (STD), such as human immunodeficiency virus (HIV), and the diagnosis of this disease can have a very large impact from a psychological point of view. All of this, can still be reflected in the aging process of a group by itself already discriminated, further increasing the difficulties that these individuals feel during a complex and adverse process.

\section{Literature Review}

\subsection{LGBT in Portugal}

Lesbian, gay, bisexual and transgender (LGBT) people must overcome particular challenges associated with their sexual orientation and frequently experience situations of social stigma (Pereira \& Rodrigues, 2015). In order to combat these challenges, several sociopolitical changes have occurred in Portugal, such as the introduction of a sexual orientation non-discrimination law, the legalization of same-sex marriage, and another law permitting homosexual couples to adopt children (Pereira \& Monteiro, 2016; Pereira \& Rodrigues, 2015). However, heterosexism still plays a dominant role in society, motivating many people to conform to societally-imposed heteronormative roles. Therefore, LGBT people represent a sexual minority, which faces a variety of situations encompassing negative social stigma, discrimination and violence at the hands of society (Meyer, 1995).

Despite the progress made at the legislature level for the LGBT community, gay and bisexual men (GBM) are still limited in Portugal by many tensions, particularly in the decision to assume or not their sexual orientation. As such, few studies have yet been conducted in Portugal regarding GBM and, in the literature review, only two with this specificity were found, which are referred to later in this article 


\subsection{Minority Stress Model}

Situations of stigma could be an underlying factor explaining the LGBT community's levels of mental and physical health, as they are considered to be stress factors that LGBT individuals must live and grow old with (Meyer, 2003). In his minority stress model, Meyer (1995) argues that the social stigma and systematic discrimination associated with sexual orientation create a stressful social context with a consequent negative impact on the health of LGBT individuals (Meyer \& Northridge, 2007). As a result, the minority stress model links psychological stress associated with situations of stigma and discrimination with mental health disorders (Tomori et al., 2016), referring four mechanisms that may be the origin of symptoms, like depression, among sexual minorities, which encompass harmful events, expectations of rejection and discrimination, hiding one's identity and internalized homophobia (Meyer, 2003). Furthermore, these mechanisms can also lead to individuals' social isolation (McAndrew \& Warne, 2010).

\subsection{Mental Health and GBM}

As previously mentioned, the mental health inequalities that exist among the LGBT community include situations of social exclusion, stigma and discrimination that are often caused by homophobia, heterosexism and the assumption of heterosexuality imposed on LGBT individuals either by society (McParland \& Camic, 2016) or by their families (Orel, 2014). This confluence of factors can consequently lead to negative mental health outcomes among the LGBT population (Meyer, 1995; 2003). Thus, LGB people tend to have poorer health outcomes when compared to their heterosexual peers (Semlyen, King, Varney, \& Hagger-Johnson, 2016), with bisexuals being the most likely to experience negative health outcomes (Bostwick, Boyd, Hughes, West, \& McCabe, 2014). GBM report higher levels of discomfort associated with their sexual orientation, not accepting themselves as they are and probably hiding their sexuality from others (McParland \& Camic, 2016), which can lead to a greater risk of psychological and emotional distress, particularly in regard to depressive symptoms (Mills et al., 2004).

In a study by Marti-Pastor et al. (2018), performed in Barcelona, Spain, LGB individuals demonstrated worse levels of health-related quality of life compared to heterosexual individuals. Marti-Pastor et al.'s study also found that the anxiety or depression prevalence rate among GBM was $185 \%$ higher than the rate found among other sexual orientation groups. Therefore, it is possible to claim that the incidence of mood and anxiety disorders is substantially higher among GBM, as they are more likely to experience depressive symptoms, panic attacks and psychological distress (Cox, 2012; King et al., 
2008). In a study by Brennan-Ing, Seidel, Larson and Karpiak (2014), carried out in the United States, gay men demonstrated higher levels of depression compared to other sexual orientation groups.

\subsection{GBM and the Aging Process}

In Portugal, it is estimated that $21,8 \%$ of the population is constituted by older people with $65+$ years, thus maintaining the aging trend demographic (Statistics Portugal, 2019). As such, the Social Security has developed a set of support measures for older individuals with the objective of promoting their autonomy, social integration and health, and these supports are partially reimbursed, considering the family's income (Segurança Social, 2016).

The aging process may offer an opportunity to consolidate individuals' strengths and resilience (McParland \& Camic, 2016), despite being a process that involves several challenges due to the loss of roles, death of loved ones, threats to independence and chronic health conditions (Hash \& Rogers, 2013). Individuals who experience the aging process often suffer from age-related discrimination (McParland \& Camic, 2016), which tends to increase among men between 40 and 50 years old and has an influential impact on their self-esteem and well-being (Lyons, Pitts, \& Grierson, 2012). There are differences in heterosexual and homosexual individuals' respective aging processes, particularly in regard to concerns that arise from experiences of social stigmatization and discrimination throughout their lives (Gardner, de Vries, \& Mockus, 2014). The current generation of older GBM has lived most of their lives during a time period when they could not openly express their sexual orientation for fear of rejection or persecution (Barrett, Whyte, Comfort, Lyons, \& Crameri, 2015; Grossman, D’Augelli, \& O'Connell, 2001), in addition to witnessing the loss of many friends with whom they had hoped to grow old (de Vries \& Croghan, 2014). They came of age in a context where their expressions of love were "diagnosed" as a mental disorder (de Vries \& Croghan, 2014), as homosexuality was classified as a sociopathic personality disorder in 1952 (McParland \& Camic, 2016). As a result, this generation of GBM was afraid to admit their desires to themselves, internalizing the negative stereotypes about their sexual orientation that were imposed upon them by society (Barrett et al., 2015; Grossman et al., 2001). Thus, much of their lives have been shaped by these factors, which may be associated with worse overall health outcomes (de Vries \& Croghan, 2014).

The levels of depression and anxiety observed in older GBM appear to be higher than those seen in the heterosexual population (Bostwick et al., 2014; Jackson et al., 
2008), contributing to varying degrees of psychological suffering that were reported by more than half of older GBM (Lyons, Pitts, \& Grierson, 2014). In a study by Pereira, de Vries, Serrano, et al. (2019), with a sample of older Spanish and Portuguese GBM, older gay men reported higher levels of depressive symptoms than older bisexual men. Similarly, a study by Morales, King, Hiler, Coopwood and Wayland (2014), conducted in the greater St. Louis region, US, discovered that older individuals who are prone to homophobic violence are more likely to be depressed and, thus, possess a greater need for socialization. The ability of GBM to maintain supportive relationships with their families becomes increasingly challenging as they get older (Orel, 2014), resulting in situations where their support networks are disproportionately dependent on friends (Brennan-Ing et al., 2014; Croghan, Moone, \& Olson, 2014). A study by Dorfman et al. (1995) demonstrated that older gay men are significantly less likely to have a partner when compared to heterosexual men. In addition, they are also more likely to not have children (de Vries \& Croghan, 2014). However, it is important to note that bisexual men are more likely to have children than any other sexual orientation group (Croghan et al., 2014).

A study by Kelly (1977), with a sample of gay men in the Los Angeles metropolitan area, showed that, while sexual orientation itself does not cause problems related to the aging process in GBM, the social stigma associated with one's sexual orientation does. Still, there may be adaptive factors that help mediate the influence of stigma and discrimination, specifically resilience (Jeste et al., 2013; McParland \& Camic, 2016) and social support from families of origin or families by choice (Caceres \& Frank, 2016), which could reduce loneliness and increase individuals' self-esteem (McParland \& Camic, 2016). As older members of the LGB community have lived much of their lives in heterosexist and homophobic societal contexts, they have developed skills to deal with crises (Caceres $\&$ Frank, 2016) that reinforce their ability to deal with future stressors (McCann, Sharek, Higgins, Sheerin, \& Glacken, 2013).

\subsection{GBM and HIV}

The human immunodeficiency virus (HIV) is still considered to be a socially disabling disease with a certain degree of stigma in Portugal (Pereira, Caldeira, \& Monteiro, 2017). Additionally, HIV transmission rates among men who have sex with men (MSM) in Portugal have doubled since 2001 (Pereira, 2014). In Portugal, HIV antiretroviral treatment is available to all citizens free of charge, as long as patients adhere to the prescribed medication regimen. However, an HIV diagnosis affects individuals' emotional and sexual lives, particularly MSM (Pereira et al., 2017), who are at a disproportionate risk of being affected by sexually transmitted diseases (Cochran, 2001). 
In a study by Brennan-Ing, Seidel, London, Cahill and Karpiak (2014), carried out in the US, older gay men were more likely to be diagnosed with HIV compared to men and women of other sexual orientations. In fact, HIV was first identified within the GBM community in the early 1980 s (Cox, 2012) and, as such, thousands of lives have been lost to this disease, decimating older GMB's social support networks and destroying their communities (de Vries \& Croghan, 2014).

Stigma and discrimination are among the biggest challenges that individuals diagnosed with HIV have to overcome and can be experienced through emotions, thoughts and/or behaviors in multiple ways (Earnshaw, Smith, Chaudoir, Amico, \& Copenhaver, 2013; Hua et al., 2014; Thomas et al., 2005) that can negatively affect the emotional, behavioral and physical health outcomes of the HIV-positive population (Earnshaw \& Chaudoir, 2009; Rueda et al., 2016). Furthermore, these challenges are often associated with poorer mental health outcomes among individuals, particularly concerning depression (Berger et al., 2001; Ciesla \& Roberts, 2001; L. Li, Lee, Thammawijaya, Jiraphongsa, \& Rotheram-Borus, 2009), low self-esteem (Kang, Rapkin, \& DeAlmeida, 2006), anxiety (Bogart, Wagner, Galvan, \& Klein, 2010; H. Li et al., 2015), lower levels of social support and reduced adherence to antiretroviral medications (Logie \& Gadalla, 2009; Rueda et al., 2016). Moreover, substandard mental health outcomes can imply consequences for individuals' self-perceptions and their emotional reactions to people who cause situations of stigma (Berger et al., 2001).

Consequently, the aging process for people living with HIV is associated with higher rates of other age-related diseases, particularly mood disorders (Cox, 2012), which can negatively impact their quality of life and aging experiences (de Vries \& Croghan, 2014). The effects of depression among HIV-positive individuals seem to be more apparent when compared to the general population (Do et al., 2014), a finding that could be associated with higher rates of disease progression (Cox, 2012). Moreover, MSM diagnosed with HIV appear to be more likely to suffer from depressive and anxious symptoms than their HIVnegative peers (Tomori et al., 2016; Wohl et al., 2013). In a study by Pereira et al. (2017), with a sample of self-identified Portuguese MSM, some reported feelings associated with a type of double stigma that simultaneously encompassed their HIV diagnosis and their sexual orientation, describing the need to deal with both social stigmas, as well as problems arising from anxiety, depression and low self-esteem.

Usually, HIV-positive GBM are individuals who have low levels of social support (Rueda et al., 2016), since many people still reject or subtly avoid these individuals (McCain \& Gramling, 1992). Thus, feelings that arise from stigmatizing situations can 
limit potential sources of social support due to fears of rejection (Berger et al., 2001). However, these same sources could act as mediators of the negative impacts arising from stigma or depressive symptoms (L. Li et al., 2009).

Considering the previously substantiated findings, the present study was carried out in order to assess mental health disparities among gay and bisexual men over 50 years old, based upon their HIV status. The mental health indicators utilized included anxiety, depression, self-esteem and resilience, with this study seeking to compare these indicators among older HIV-positive and HIV-negative gay and bisexual men. Furthermore, this study also sought to determine the respective predictive effects of resilience and selfesteem on the mental health of older GBM.

\section{Methodology}

\subsection{Study Design}

The present study can be classified as a quantitative, descriptive study, since it allows the identification, registration and analysis of variables, describing how they behave in the sample. It is also a comparative study, insofar as it is intended to compare how the variables behave between two different groups. It is likewise considered a crosssectional study, as it measures the frequency of manifestation of an event in a population, at a given time.

\subsection{Instrumentation}

Sample participants' sociodemographic information was collected using a questionnaire. Participants were asked about their age, sexual orientation, place of residence, professional status, educational attainment, socioeconomic status, marital status and social support networks, among other characteristics. Participants also responded to the Rosenberg Self-Esteem Scale, a brief measurement instrument that assesses the self-esteem levels of adolescents and adults and which consists of 10 items that are evaluated using a 4-point Likert scale. The Rosenberg Self-Esteem Scale scores vary between $\mathrm{o}$ and 30 points, with higher scores indicating higher self-esteem, and vice versa (Pechorro, Marôco, Poiares, \& Vieira, 2011). The Brief Symptom Inventory 18 (BSI18) is comprised of 18 items and was applied in order to evaluate the psychosymptomatology experienced by individuals over the previous week, using three subscales - somatization, depression and anxiety. The depression subscale focuses on the 
core symptoms of depressive disorders, which include dysphoric mood states and anhedonia, among others. In turn, the anxiety subscale encompasses symptoms indicative of panic states, such as nervousness, tension and motor agitation. The global severity index is obtained by adding the scale's 18 items together, providing a measurement of individuals' general psychological distress levels, with higher scores revealing more intense psychosymptomatology (Nazaré, Pereira, \& Canavarro, 2017). Finally, this study measured participants' resilience using the Connor-Davidson Resilience Scale 10 (CDRISC-10), which consists of 10 items assessed using a Likert scale ranging from o to 4 points. The CDRISC-10 asks subjects to evaluate statements and the extent to which they applied to the subjects' lives over the past month (Almeida, 2016). Resilience levels were evaluated based on the total sum of all items of this self-response scale, with higher scores reflecting higher levels of resilience (Davidson, 2018). Finally, it is important to note that this study utilized the Portuguese versions of the respective aforementioned measurement instruments.

\subsection{Study Analytic Methods}

Following study approval by the researchers' university's ethics committee and the careful consideration of the study objectives, a form was subsequently disseminated online between August 2019 and September 2019, and a secure online website was created for research purposes. Individuals were invited to participate on a voluntary basis through a link specifically aimed at GBM over 50 years old, which was sent via internet notifications and advertisements to LGBT organizations, using social networks and email addresses. All advertisements took participants directly to the online site, which explained the study's objectives, the participant's freedom to withdraw from the study at any time, how to contact the authors in order to obtain more information about the study, any associated ethical issues and participant instructions. All ethical and deontological principles were respected, ensuring compliance with all existing norms, such as informed consent, confidentiality and the anonymity of participants' identities and the study results. No financial compensation was awarded in exchange for participating in the study, and the data collected were used exclusively for statistical purposes.

Subsequently, participants' submitted online data was entered into IBM $₫$ SPSS $®$ STATISTICS (version 26). This statistical program was used to build the study database and prepare for its statistical analysis, using several procedures necessary to describe and compare the behavior of the variables under study. Subsequently, the study sample underwent descriptive data analysis, which considered the nature of the variables under study, calculating their descriptive statistics, particularly their respective means, standard deviations and maximums and minimums. Cronbach's alphas were utilized to verify the 
internal consistency and estimate the reliability of the study questionnaire that encompassed the Rosenberg Self-Esteem Scale, the BSI-18 and its depression and anxiety subscales and the CDRISC-10. The aforementioned scales and subscales possessed Cronbach's alphas equal to $.85, .93, .91, .86$ and .94 , respectively. As a result, it is possible to conclude that the study questionnaire possesses a very satisfactory degree of reliability. In order to test the associations and differences among variables, this study conducted ttests, Pearson's correlation tests and linear regressions. T-tests for independent samples were used to determine if the respective dependent variable means in the groups being compared differed significantly from one other. In turn, Pearson's correlation tests were utilized to verify whether two or more interval variables were associated with one other (Martins, 2011). Additionally, the study conducted linear regressions to construct a hierarchical analysis of the study variables, in order to assess the effects of a given variable on another variable. Finally, it is important to note that the significance level was set at $\mathrm{p}=$ .05 for all statistical analyses concerning the study sample.

\subsection{Sample Description}

The study sample consisted of 201 men between the ages of 50 and 79 years old. The median age of sample members was 58 years old; the mean age was 58.85 years old, and the standard deviation was 6.205. Regarding sexual orientation, 162 individuals (80.6\%) identified themselves as gay, while 28 participants (13.9\%) self-identified as bisexual. 34 sample participants (16.9\%) claimed to be HIV-positive. Regarding participants' professional status, 138 participants (68.7\%) were employed, while 14 (7.0\%) were unemployed. Concerning educational attainment, the majority of sample members possessed a tertiary education, with 67 individuals (33.3\%) claiming to have a bachelor's degree, 46 (22.9\%) holding a master's degree and 25 (12.4\%) possessing a PhD. Regarding participants' socioeconomic status, 5 participants (2.5\%) claimed that they belonged to the lowest socioeconomic group (very low), 19 individuals (9.5\%) to the second-lowest group (low), 138 (68.7\%) to the middle group (medium), 38 (18.9\%) to the second-highest group (high), and 1 (.5\%) to the highest group (very high). In regard to marital status, just over half of sample members reported being single (51.7\%). Concerning participants' living situations, a slight majority claimed to live alone (51.2\%). The corresponding sociodemographic data for the sample is shown in Table 1. 
Table 1:

Sociodemographic data of sample participants

\begin{tabular}{|c|c|c|c|c|c|}
\hline & & & & & \\
\hline & & $n$ & $\%$ & Mean & S.D. \\
\hline Age & & & & 58.85 & 6.205 \\
\hline \multirow[t]{2}{*}{ Sexual orientation } & Gay & 162 & 80.6 & & \\
\hline & Bisexual & 28 & 13.9 & & \\
\hline \multirow[t]{2}{*}{ HIV status } & $\mathrm{HIV}+$ & 34 & 16.9 & & \\
\hline & HIV - & 167 & 83.1 & & \\
\hline \multirow[t]{4}{*}{ Professional status } & Employed & 138 & 68.7 & & \\
\hline & Unemployed & 14 & 7.0 & & \\
\hline & Retired & 38 & 18.9 & & \\
\hline & Disability Recipient & 6 & 3.0 & & \\
\hline \multirow{5}{*}{$\begin{array}{l}\text { Educational } \\
\text { attainment }\end{array}$} & Middle school & 17 & 8.5 & & \\
\hline & High school & 42 & 20.9 & & \\
\hline & Bachelor's degree & 67 & $33 \cdot 3$ & & \\
\hline & Master's degree & 46 & 22.9 & & \\
\hline & Doctorate/PhD & 25 & 12.4 & & \\
\hline \multirow{5}{*}{$\begin{array}{l}\text { Socioeconomic } \\
\text { status }\end{array}$} & Very low & 5 & 2.5 & & \\
\hline & Low & 19 & 9.5 & & \\
\hline & Medium & 138 & 68.7 & & \\
\hline & High & 38 & 18.9 & & \\
\hline & Very high & 1 & .5 & & \\
\hline \multirow[t]{9}{*}{ Marital status } & Single & 104 & 51.7 & & \\
\hline & Dating & 21 & 10.4 & & \\
\hline & Living with a partner & 18 & 9.0 & & \\
\hline & De facto same-sex union & 13 & 6.5 & & \\
\hline & Same-sex marriage & 18 & 9.0 & & \\
\hline & De facto opposite-sex union & 2 & 1.0 & & \\
\hline & Opposite-sex marriage & 18 & 9.0 & & \\
\hline & Divorced/separated & 5 & 2.5 & & \\
\hline & Widower & 1 & .5 & & \\
\hline \multirow[t]{7}{*}{ Living situation } & Living alone & 103 & 51.2 & & \\
\hline & Living with a partner & 35 & 17.4 & & \\
\hline & Living with husband/wife & 30 & 14.9 & & \\
\hline & Living with children & 4 & 2.0 & & \\
\hline & $\begin{array}{l}\text { Living with } \\
\text { parents/dad/mother }\end{array}$ & 13 & 6.5 & & \\
\hline & Living with friends & 9 & $4 \cdot 5$ & & \\
\hline & Other & 3 & 1.5 & & \\
\hline \multirow[t]{2}{*}{ Brothers/Sisters } & Yes & 165 & 82.1 & & \\
\hline & No & 34 & 16.9 & & \\
\hline \multirow[t]{2}{*}{ Children } & Yes & 62 & 30.8 & & \\
\hline & No & 138 & 68.7 & & \\
\hline
\end{tabular}




\section{Results}

Regarding self-esteem, study participants displayed a mean of 3.35 with a standard deviation of .51. For depression, the sample mean was .76 and the standard deviation was .82. Concerning anxiety, the study found a sample mean of .65 and a standard deviation of .67. Finally, results concerning participants' resilience obtained a mean of 4.12 and a standard deviation of .76. Consequently, it appears that the sample revealed moderate levels of self-esteem, below average levels of depression and anxiety in comparison with the general population and higher levels of resilience than were expected. The table below presents summary statistics for each of the study variables.

Table 2:

Self-esteem, depression, anxiety and resilience levels

\begin{tabular}{lccccc} 
& Mean & Median & S.D. & Minimum & Maximum \\
\cline { 2 - 5 } Self-esteem & 3.35 & 3.45 & .51 & 1.30 & 4.00 \\
Depression & .76 & .50 & .82 & .00 & 3.67 \\
Anxiety & .65 & .50 & .67 & .00 & 3.33 \\
Resilience & 4.12 & 4.20 & .76 & 1.00 & 5.00 \\
\hline
\end{tabular}

This study utilized independent samples t-tests to verify whether the dependent variables' respective means in the two comparison groups differed significantly from each other. The t-tests revealed significant differences concerning the association between selfesteem and sexual orientation ( $\mathrm{p}=.03$ ), with older bisexual men presenting higher levels of self-esteem $(\mathrm{m}=3.55)$ compared to older gay men $(\mathrm{m}=3.31)$. The research also observed statistically significant differences regarding the relationship between depression and sexual orientation ( $\mathrm{p}=.05$ ), with older gay men showing higher levels of depression $(\mathrm{m}=.81)$ when compared to older bisexual men $(\mathrm{m}=.49)$. Concerning resilience, statistically significant differences were also found in relation to sexual orientation ( $\mathrm{p}=$ .04), as older bisexual men demonstrated higher levels of resilience $(\mathrm{m}=4.40)$ in comparison with older gay men $(\mathrm{m}=4.06)$.

Regarding comparisons based upon HIV status, no statistically significant differences were found between HIV-positive and HIV-negative men. However, the study observed differences in the mean reported levels of self-esteem, depression, anxiety, and resilience, with HIV-positive men generally reporting poorer mental health outcomes. A summary of the aforementioned results is displayed below, in Table 3 . 
Table 3:

Independent samples t-tests - sexual orientation and HIV status

\begin{tabular}{|c|c|c|c|c|c|}
\hline & $\mathbf{N}$ & Mean & S.D. & t (gl) & $\mathbf{p}$ \\
\hline \multicolumn{6}{|c|}{ Self-esteem } \\
\hline Gay & 155 & $3 \cdot 31$ & .53 & \multirow{2}{*}{-2.20} & \multirow{2}{*}{.03} \\
\hline Bisexual & 26 & 3.55 & .43 & & \\
\hline HIV+ & 31 & 3.30 & .57 & \multirow{2}{*}{-.52} & \multirow{2}{*}{.61} \\
\hline HIV- & 161 & $3 \cdot 36$ & .50 & & \\
\hline \multicolumn{6}{|c|}{ Depression } \\
\hline Gay & 158 & .81 & .84 & \multirow{2}{*}{1.93} & \multirow{2}{*}{.05} \\
\hline Bisexual & 28 & .49 & .70 & & \\
\hline HIV+ & 34 & .87 & .90 & \multirow{2}{*}{.88} & \multirow{2}{*}{.38} \\
\hline HIV- & 163 & .74 & .81 & & \\
\hline \multicolumn{6}{|l|}{ Anxiety } \\
\hline Gay & 155 & .68 & .67 & \multirow{2}{*}{1.67} & \multirow{2}{*}{.09} \\
\hline Bisexual & 27 & .45 & .62 & & \\
\hline HIV+ & 32 & .71 & .76 & \multirow{2}{*}{.60} & \multirow{2}{*}{.55} \\
\hline HIV- & 160 & .64 & .65 & & \\
\hline \multicolumn{6}{|c|}{ Resilience } \\
\hline Gay & 159 & 4.06 & .79 & \multirow[b]{2}{*}{-2.07} & \multirow[b]{2}{*}{.04} \\
\hline Bisexual & 26 & 4.40 & .64 & & \\
\hline $\mathrm{HIV+}$ & 33 & 3.94 & .82 & \multirow{2}{*}{-1.44} & \multirow{2}{*}{.15} \\
\hline HIV- & 163 & 4.15 & .75 & & \\
\hline
\end{tabular}

This study performed Pearson's correlation coefficient tests to verify the significance of the study variables, as well as to describe both the strength and linear direction of any correlations among them, verifying how one variable can influence another. Consequently, it was possible to observe that all results were statistically significant, as their significance levels were less than .05.

The study results found that self-esteem is negatively correlated with both depression ( $\mathrm{r}=-.539)$ and anxiety $(\mathrm{r}=-.476)$, which suggests that higher levels of selfesteem imply lower levels of depression and anxiety. Conversely, self-esteem is positively correlated with resilience $(\mathrm{r}=.517)$ and, as such, higher levels of self-esteem are likely to be observed alongside higher levels of resilience. Depression is negatively correlated with resilience ( $\mathrm{r}=-.440)$, suggesting that higher levels of depression are related to lower levels of resilience. Conversely, depression is positively correlated with anxiety $(r=.805)$, allowing the study to infer that higher levels of depression are associated with higher levels of anxiety. Finally, anxiety is negatively correlated with resilience ( $\mathrm{r}=-.338$ ), demonstrating that more elevated levels of anxiety are likely to result in lower levels of resilience. The previously described results are shown in Table 4. 
Table 4:

Correlation levels among variables

\begin{tabular}{lcccc}
\hline & Self-esteem & Depression & Anxiety & Resilience \\
\hline Self-esteem & 1 & & \\
\hline Depression & -.539 & 1 & \\
& & & \\
& .000 & & \\
\hline Anxiety & -.476 & .805 & 1 & \\
& .000 & .000 & & \\
\hline Resilience & .517 & -.440 & -.338 & \\
& 0.000 & .000 & .000 & \\
\hline
\end{tabular}

Finally, this study conducted a hierarchical multiple regression analysis, in order to assess the effects of age, self-esteem and resilience on symptoms of depression and anxiety among older GBM, verifying that the predictor variables significantly explain the criterion variables $(\mathrm{p}<.01)$. The first model of analysis explains $33 \%$ of the general variation of depressive symptoms, while the second model explains $25 \%$ of the variation of anxious symptoms. Consequently, it is possible to observe that lower levels of self-esteem and resilience are predictors of depressive symptoms, and that lower levels of self-esteem are also predictors of anxious symptoms. These results are described in further detail in Table 5 .

Table 5:

Linear regression models (Model I - Depressive symptoms; Model II -Anxious symptoms)

\begin{tabular}{|c|c|c|c|c|c|c|}
\hline \multirow[b]{2}{*}{ Variable } & \multicolumn{3}{|c|}{ Model I } & \multicolumn{3}{|c|}{ Model II } \\
\hline & $\boldsymbol{B}$ & $S E B$ & $\beta$ & $\boldsymbol{B}$ & $S E B$ & $\boldsymbol{\beta}$ \\
\hline Age & -.001 & .009 & -.008 & -.005 & .008 & -.047 \\
\hline Self-esteem & -.716 & .116 & $-.433^{*}$ & -.557 & .099 & $-.426^{*}$ \\
\hline Resilience & -.242 & .077 & $-.221^{*}$ & -.093 & .065 & -.109 \\
\hline $\mathrm{R}^{2}$ & .333 & & & .250 & & \\
\hline $\mathrm{F}$ for change in $\mathrm{R}^{2}$ & $30.26^{*}$ & & & $19.71^{*}$ & & \\
\hline
\end{tabular}




\section{Discussion}

Portugal is, at this moment, one of the few countries that includes in its legislation decrees that protect the LGBT community, which can lead to a greater visibility of these individuals, generating diverse challenging and problematic scenarios for people belonging to the LGBT community, especially if they are older and diagnosed with HIV. As such, this study sought to explore the relationships among mental health, sexual orientation and HIV status. Among the total sample of 201 men, the majority of participants possess a tertiary education (68.6\%), belong to the middle or second-highest socioeconomic groups (88.1\%), are single (51.7\%), live alone (51.2\%) and have no children (68.7\%), while a significant minority are HIV-positive (16.9\%).

\subsection{Mental Health and GBM}

Contrary to the researchers' initial expectations, the study results demonstrated that the sample of older GBM possesses well-balanced mental health indicators, reporting moderate levels of self-esteem and high levels of resilience, as well as lower average levels of depression and anxiety than found among the general population. These results may be associated with the fact that these men have developed the necessary skills to deal with mental health challenges throughout their lives (Caceres \& Frank, 2016; Heaphy, 2007). In the case of older LGBT individuals, many have had opportunities to build a sense of resistance and competence throughout their lives, surviving as members of a sexual minority in a heterosexual societal context (de Vries \& Croghan, 2014) and developing adaptive coping strategies to deal with the stress that they have been subjected to (Brown, Alley, Sarosy, Quarto, \& Cook, 2002). In a study by Orel (2014), participants reported that being an LGBT person prepared them for the aging process, as the ability and the need to deal with discrimination and overcome adversity throughout their lives had equipped them with many necessary abilities to confront the difficulties implicit to the aging process. In this light, LGBT individuals are better prepared to accept the realities of aging when compared to their heterosexual peers (Friend, 1991), as they have already successfully overcome other adverse situations over the course of their lives (Fenkl, 2012). Another study by Brown et al. (2002) also revealed that older gay men demonstrate higher levels of resilience and problem-solving abilities than those observed among the general population.

Older bisexual men showed higher levels of self-esteem and resilience compared to their homosexual peers, who revealed higher levels of depression. These results may be associated with a greater degree of social support present among older bisexual men, as social support is considered to be one of the fundamental factors behind successful aging 
processes (Fenkl, 2012). Older bisexual men may be in a relationship with someone of the opposite sex, have children, and have more people in their support networks, all of which help to overcome difficulties related to the aging process. In addition, older bisexual men may also have learned to manage difficulties in resolving crises (Porter, Brennan-Ing, Burr, Dugan, \& Karpiak, 2019) and when confronting stigma, possibly overcoming the homophobia that they may have been subjected to due to their sexual minority status.

In regard to the presence of symptoms of depression and anxiety, it is important to highlight that the most common comorbid disorders found among people with mood disorders are anxiety disorders (Viana \& Lourenço, 2017). Usually, individuals with depression restrict their social activities due to a loss of interest and pleasure, or even because of anxious symptoms. In turn, individuals with anxiety present more severely disabled personal functioning, as well as a greater risk of developing a depressive condition (D’El Rey \& Freedner, 2006). Therefore, anxious symptoms are usually closely related to symptoms of depression (Pais-Ribeiro, Honrado, \& Leal, 2004), particularly feelings of malaise, anguish, nausea, sadness and worry (Viana \& Lourenço, 2017). This finding stresses the importance of recognizing the overlap between anxiety and depression from both a mental health and statistical point of view (Pais-Ribeiro et al., 2004). The association between depression and anxiety was corroborated by the results of this study, as our findings indicate that higher levels of depression were found in conjunction with higher levels of anxiety.

Simultaneously, it appears that greater levels of resilience result in more elevated levels of self-esteem, and vice versa. These results may be associated with the fact that building and maintaining self-esteem function as protective mechanisms, increasing in sync with higher levels of resilience (Quinton \& Rutter, 1984). A study by César (2015) observed that resilience had both a significant and a predictive effect on self-esteem, affirming that greater resilience levels increase self-esteem. As resilience is related to mechanisms for overcoming adversity, this likely results in improved self-esteem (César, 2015). Additionally, more elevated levels of self-esteem can better prepare individuals to deal with adversity (Branden, 2009).

Low levels of self-esteem can often lead to several mental health disorders (Guerreiro, 2011), including anxiety disorders and mood disorders (Branden, 2009; Guimarães, 2012). Nevertheless, as previously mentioned, this study's sample possesses moderate levels of self-esteem, indicating that higher levels of self-esteem are related to lower levels of depression and anxiety.

The study results also show that the models tested to explain symptoms of depression and anxiety are statistically significant, with lower levels of self-esteem and resilience being predictors of depressive symptoms, while solely lower levels of self-esteem 
were predictors of anxious symptoms. Resilience is a concept associated with positive adaptation in the face of significant challenges. Consequently, people with greater resilience experience better emotional and functional well-being, thus, resilience can reduce the negative effects of stress (Fang et al., 2015), justifying the results found in this study.

\subsection{GBM and HIV}

Previous research indicates that lower socioeconomic status may be related to higher levels of HIV infection and depression (Do et al., 2014). Thus, it is important to note that this study's sample consisted of individuals who mostly pertained to middle and upper socioeconomic groups, who are well-educated and financially comfortable. This sample characteristic should be taken into account, since it could be an indicator of individuals' access to healthcare resources, in addition to possibly affecting the knowledge and behaviors associated with the general health status of individuals (Do et al., 2014), so it may be an over-representation of the healthier members of this minority group. Similarly, a study by Brown et al. (2002) identified financial stability as one of the primary aging adaptation qualities among older gay men.

Some studies have linked an HIV diagnosis with depressive (Vanable, Carey, Blair, \& Littlewood, 2006; Wohl et al., 2013) and anxious (Courtenay-Quirk, Wolitski, Parsons, \& Gómez, 2006) symptoms. As a result, this study predicted that older HIV-positive GBM would display worse mental health outcomes when compared to older HIV-negative GBM. However, this study found no significant differences between HIV-positive and HIVnegative GBM. These results can be partially explained by the high levels of resilience observed among sample participants and the fact that more resilient individuals are less likely to suffer from symptoms of anxiety, depression and low self-esteem (Carvalho et al., 2016). These findings could be explained by the fact that is likely that the sample participants have developed appropriate coping strategies to deal with a possible HIV diagnosis and/or their sexual orientation, in order to moderate stigma's effects on their mental health. Another possible explanation centers on participants' interactions with healthcare systems that assist them in maintaining high adherence to antiretroviral therapy, which, in turn, is associated with a higher quality of life.

\section{Limitations and Future Directions}

Nevertheless, this study possesses certain limitations. For example, it was conducted using a convenience sample, which raises doubts about its representativeness of the general Portuguese homosexual and bisexual populations, respectively. In addition, there 
are high levels of heterogeneity in the groups under study, particularly among homosexual ( $n=162)$ and HIV-negative $(n=167)$ participants. Consequently, the study results may have been unduly influenced by larger groups of participants. Further possible limitations could arise from the fact that this study conducted data collection using a questionnaire published on social networks aimed at gay and bisexual men, which may have limited its ability to capture men who do not utilize these same networks, possibly biasing the sample selection. Furthermore, older GBM are often individuals who consider themselves to form a part of an invisible group and, consequently, are less likely to participate in studies concerning GBM (Marques \& Sousa, 2016). In turn, this may result in sample selection bias characterized by an over-representation of the healthier members of this minority group. Another limitation concerns the fact that this study utilized participants' selfreported HIV statuses, which were not subsequently corroborated through clinical evaluations or medical records.

\subsection{Recommendations}

It is recommended that future research improve knowledge and data collection concerning older GBM by utilizing additional measurement instruments and larger samples with a greater number of bisexual and HIV-positive men, in order to enhance the reliability of statistical data analysis. Differences between GBM who were in the closet versus those who are out were not were not analyzed in the present study, however it should be a topic to consider for future studies. Ideally, future studies would also examine heterosexual subjects to facilitate comparisons among sexual orientation groups. Another recommendation would be to conduct similar studies in different international contexts, increasing the number of gerontological studies concerning homosexual and bisexual communities and facilitating the development of strategies to combat the discrimination and stigma faced by these individuals. Future research suggestions include an increased focus on older GBM's families, as families have been proven to be an important source of social support for GBM and for HIV-positive men, rendering it essential to understand their perspectives, especially when conducting effective social support interventions.

\section{Implications}

Mental and physical health professionals should be aware that the effects of stigma and other variables on health of LGBT people can vary between different LGBT subgroups. As such, healthcare providers should assess the importance of stressors related to sexual minority status with each individual, making no assumptions about their harmful effects, as each person reacts and handles stressors and situations differently. In addition, when 
we add the age and HIV diagnosis variables, these individuals face a series of increased clinical challenges due to the fact that their immune recovery is slower (E. J. Mills, Bärnighausen, \& Negin, 2012), having less power to access health resources compared to heterosexual people (Link \& Phelan, 2001) As such, it is vital to emphasize the importance of training healthcare professionals to reduce stigma and discrimination against older and/or HIV-positive GBM, in order to create a more favorable clinical environment for these individuals, which will help them identify those who are at risk of depression, anxiety or other mental health problems. Furthermore, given the complexity of HIV treatment, healthcare professionals may also require training regarding issues associated with the clinical treatment of any depressive or anxious symptoms that affect these individuals. In addition, LGBT organizations and groups must begin to give more prominence to a population that often ends up being forgotten and, as such, it is essential that issues such as aging or HIV diagnosis start to be increasingly mentioned, being discussed resources and information necessary for these individuals.

\section{Conclusion}

The literature review performed by this study revealed that no studies concerning the relationships among mental health variables, aging in GBM and diagnosis of HIV have been conducted in Portugal to date. As a result, this study offers a pioneering contribution to the literature on aging and mental health among older GBM in Portugal. Moreover, this project aims to give a voice to older HIV-positive and HIV-negative GBM in Portugal, in order to gain a better understanding of the barriers and obstacles that they face throughout the aging process.

\section{References}

Almeida, R. F. (2016). A resiliência e a sintomatologia psicopatológica numa amostra da população geral portuguesa. [Dissertação de Mestrado, Universidade de Lisboa]. Retrieved from http://hdl.handle.net/10451/25102

Apoios Sociais e Programas. (2016). Retrieved from Segurança Social website: http://www.seg-social.pt/idosos

Barrett, C., Whyte, C., Comfort, J., Lyons, A., \& Crameri, P. (2015). Social connection, relationships and older lesbian and gay people. Sexual and Relationship Therapy, 
30(1), 131-142. https://doi.org/10.1080/14681994.2014.963983

Berger, B. E., Ferrans, C. E., \& Lashley, F. R. (2001). Measuring stigma in people with HIV: Psychometric assessment of the HIV stigma scale. Research in Nursing and Health, 24, 518-529. https://doi.org/10.1002/nur.10011

Bogart, L. M., Wagner, G. J., Galvan, F. H., \& Klein, D. J. (2010). Longitudinal relationships between antiretroviral treatment adherence and discrimination due to HIV-serostatus, race, and sexual orientation among African-American men with HIV. Annals of Behavioral Medicine, 40, 184-190. https://doi.org/10.1007/s1216o-0109200-x

Bostwick, W. B., Boyd, C. J., Hughes, T. L., West, B. T., \& McCabe, S. E. (2014). Discrimination and mental health among lesbian, gay, and bisexual adults in the United States. American Journal of Orthopsychiatry, 84(1), 35-45. https://doi.org/10.1037/hoog8851

Branden, N. (2009). A importância da auto-estima. In Como aumentar sua auto-estima (pp. 10-15). Sextante.

Brennan-Ing, M., Seidel, L., Larson, B., \& Karpiak, S. E. (2014). Social care networks and older LGBT adults: Challenges for the future. Journal of Homosexuality, 61(1), 2152. https://doi.org/10.108o/oo918369.2013.835235

Brennan-Ing, M., Seidel, L., London, A. S., Cahill, S., \& Karpiak, S. E. (2014). Service utilization among older adults with HIV: The joint association of sexual identity and gender. Journal of Homosexuality, 61(1), 166-196. https://doi.org/10.1080/00918369.2013.835608

Brown, L. B., Alley, G. R., Sarosy, S., Quarto, G., \& Cook, T. (2002). Gay men: Aging well! Journal of Gay and Lesbian Social Services, 13(4), 41-54. https://doi.org/10.1300/Jo41v13no4

Caceres, B. A., \& Frank, M. O. (2016). Successful ageing in lesbian, gay and bisexual older people: A concept analysis. International Journal of Older People Nursing, 1-10. https://doi.org/10.1111/opn.12108

Carvalho, I. G., Santos Bertolli, E., Paiva, L., Rossi, L. A., Dantas, R. A., \& Pompeo, D. A. (2016). Ansiedade, depressão, resiliência e autoestima em indivíduos com doenças cardiovasculares. Revista Latino-Americana de Enfermagem, 24, 1-10. 
https://doi.org/10.1590/1518-8345.1405.2836

César, P. (2015). A resiliência como fator protetor para a autoestima e o bem-estar subjetivo em idosos institucionalizados. [Dissertação de Mestrado, Universidade Lusófona de Humanidades e Tecnologia]. Retrieved from http://hdl.handle.net/10437/6867

Cochran, S. D. (2001). Emerging issues in research on lesbians' and gay men's mental health: Does sexual orientation really matter? American Psychologist, 56(11), 931947. https://doi.org/10.1037/ooo3-066X.56.11.931

Connor, K., \& Davidson, J. (2018). Connor-Davidson Resilience Scale (CD-RISC) manual. https://doi.org/10.1002/da.10113

Courtenay-Quirk, C., Wolitski, R., Parsons, J., \& Gómez, C. (2006). Is HIV/AIDS stigma dividing the gay community? Perceptions of HIV-positive men who have sex with men. AIDS Education and Prevention, 18(1), 56-67.

Cox, S. (2012). Living on the edge: Gay men, depression and risk-taking behaviors. The Medius Institute for Gay Men's Health, 1-43.

Croghan, C. F., Moone, R. P., \& OLson, A. M. (2014). Friends, family and caregiving among midlife and older lesbian, gay, bisexual and transgender adults. Journal of Homosexuality, 61(1), 79-102. https://doi.org/10.108o/o0918369.2013.835238

D’El Rey, G. J., \& Freedner, J. J. (2006). Depressão em pacientes com fobia social. Psicologia Argumento, 24(46), 71-76. https://doi.org/10.7213/rpa.v24i46.20197

de Vries, B., \& Croghan, C. F. (2014). LGBT aging: The contributions of community-based research. Journal of Homosexuality, 61(1), 1-20. https://doi.org/10.1080/00918369.2013.834794

Do, A. N., Rosenberg, E. S., Sullivan, P. S., Beer, L., Strine, T. W., Schulden, J. D., ... Skarbinski, J. (2014). Excess burden of depression among HIV-infected persons receiving medical care in the United States: Data from the Medical Monitoring Project and the Behavioral Risk Factor Surveillance System. PLoS ONE, 9(3), 1-10. https://doi.org/10.1371/journal.pone.0092842

Dorfman, R., Walters, K., Burke, P., Hardin, L., Karanik, T., Raphael, J., \& Silverstein, E. (1995). Old, sad and alone: The myth of the aging homosexual. Journal of Gerontological Social Work, 24(1-2), 29-44. 
https://doi.org/10.1300/Jo83V24No1_04

Earnshaw, V. A., Smith, L. R., Chaudoir, S. R., Amico, K. R., \& Copenhaver, M. M. (2013). HIV stigma mechanisms and well-being among PLWH: A test of the HIV Stigma Framework. AIDS and Behavior, 17, 1785-1795. https://doi.org/10.1007/s10461013-0437-9

Fang, X., Vincent, W., Calabrese, S. K., Heckman, T. G., Sikkema, K. J., Humphries, D. L., \& Hansen, N. B. (2015). Resilience, stress, and life quality in older adults living with HIV/AIDS. Aging and Mental Health, 19(11), 1015-1021. https://doi.org/10.1080/13607863.2014.1003287

Fenkl, E. A. (2012). Aging gay men: A review of the literature. Journal of LGBT Issues in Counseling, 6(3), 162-182. https://doi.org/10.1080/15538605.2012.711514

Friend, R. A. (1991). Older lesbian and gay people: A theory of successful aging. Journal of Homosexuality, 20(3-4), 99-118. https://doi.org/10.1300/Joo2v14no3_12

Gardner, A. T., de Vries, B., \& Mockus, D. S. (2014). Aging out in the desert: Disclosure, acceptance, and service use among midlife and older lesbians and gay men. Journal of Homosexuality, 61(1), 129-144. https://doi.org/10.1080/00918369.2013.835240

Grossman, A. H., D’Augelli, A. R., \& O’Connell, T. S. (2001). Being lesbian, gay, bisexual, and 60 or older in North America. Journal of Gay and Lesbian Social Services, 13(4), 23-40. https://doi.org/10.1300/Jo41v13no4

Guerreiro, D. P. (2011). Necessidade psicológica de auto-estima/auto-crítica: Relação com bem-estar e distress psicológico. [Dissertação de Mestrado, Universidade de Lisboa]. $\quad$ Retrieved from http://repositorio.ul.pt/bitstream/10451/4960/1/ulfpieo39658_tm.pdf

Guimarães, J. V. (2012). Autoconceito, autoestima e comportamentos desviantes em adolescentes. [Dissertação de Mestrado, ISPA - Instituto Universitário].

Hash, K. M., \& Rogers, A. (2013). Clinical practice with older LGBT clients: Overcoming lifelong stigma through strength and resilience. Clinical Social Work Journal, 41, 249-257. https://doi.org/10.1007/s10615-013-0437-2

Heaphy, B. (2007). Sexualities, gender and ageing: Resources and social change. Current Sociology, 55(2), 193-210. https://doi.org/10.1177/o011392107073301 
Hua, J., Emrick, C. B., Golin, C. E., Liu, K., Pan, J., Wang, M., ... Jiang, N. (2014). HIV and stigma in Liuzhou, China. AIDS and Behavior, 18, 203-211. https://doi.org/10.1007/s10461-013-0637-3

Instituto Nacional de Estatística: Statistics Portugal. (2019). Estatísticas Demográficas 2018. Retrieved from https://www.ine.pt/xurl/pub/358632586

Jackson, N. C., Johnson, M. J., \& Roberts, R. (2008). The potential impact of discrimination fears of older gays, lesbians, bisexuals and transgender individuals living in small- to moderate-sized cities on long-term health care. Journal of Homosexuality, 54(3), 325-339. https://doi.org/10.1080/o0918360801982298

Jeste, D. V., Savla, G. N., Thompson, W. K., Vahia, I. V., Glorioso, D. K., Martin, A. S., ... Depp, C. A. (2013). Association between older age and more successful aging: Critical role of resilience and depression. American Journal of Psychiatry, 170(2), 188-196. https://doi.org/10.1176/appi.ajp.2012.12030386

Kang, E., Rapkin, B. D., \& DeAlmeida, C. (2006). Are psychological consequences of stigma enduring or transitory? A longitudinal study of HIV stigma and distress among Asians and Pacific Islanders living with HIV illness. AIDS Patient Care and STDs, 20(10), 712-723.

Kelly, J. (1977). The aging male homosexual: Myth and reality. Gerontologist, 17(4), 328332. https://doi.org/10.1093/geront/17.4.328

King, M., Semlyen, J., Tai, S. S., Killaspy, H., Osborn, D., Popelyuk, D., \& Nazareth, I. (2008). A systematic review of mental disorder, suicide, and deliberate self-harm in lesbian, gay and bisexual people. BMC Psychiatry, 8(70), 1-17. https://doi.org/10.1186/1471-244X-8-70

Li, H., Holroyd, E., Lau, J., \& Li, X. (2015). Stigma, subsistence, intimacy, face, filial piety, and mental health problems among newly HIV-diagnosed men who have sex with men in China. Journal of the Association of Nurses in AIDS Care, 1-29. https://doi.org/10.1016/j.jana.2015.02.004

Li, L., Lee, S. J., Thammawijaya, P., Jiraphongsa, C., \& Rotheram-Borus, M. J. (2009). Stigma, social support, and depression among people living with HIV in Thailand. AIDS Care - Psychological and Socio-Medical Aspects of AIDS/HIV, 21(8), 10071013. https://doi.org/10.108o/09540120802614358 
Link, B. G., \& Phelan, J. C. (2001). Conceptualizing stigma. Annual Review of Sociology, 27, 363-385. https://doi.org/10.1146/annurev.soc.27.1.363

Logie, C., \& Gadalla, T. M. (2009). Meta-analysis of health and demographic correlates of stigma towards people living with HIV. AIDS Care - Psychological and SocioMedical Aspects of AIDS/HIV, 21(6), 742-753. https://doi.org/10.1080/09540120802511877

Lyons, A., Pitts, M., \& Grierson, J. (2012). Growing old as a gay man: Psychosocial wellbeing of a sexual minority. Research on Aging, 35(3), 275-295. https://doi.org/10.1177/0164027512445055

Lyons, A., Pitts, M., \& Grierson, J. (2014). Sense of coherence as a protective factor for psychological distress among gay men: A prospective cohort study. Anxiety, Stress and Coping: An International Journal, 27(6), 662-677. https://doi.org/10.1080/10615806.2014.887071

Marques, F. D., \& Sousa, L. (2016). Portuguese older gay men: Pathways to family integrity. Paideia, 26(64), 149-159. https://doi.org/10.1590/1982-43272664201602

Marti-Pastor, M., Perez, G., German, D., Pont, A., Garin, O., Alonso, J., ... Ferrer, M. (2018). Health-related quality of life inequalities by sexual orientation: Results from the Barcelona Health Interview Survey. PLoS ONE, 13(1), 1-15. https://doi.org/10.1371/journal.pone.0191334

Martins, C. (2011). Manual de análise de dados quantitativos com recurso ao IBM SPSS: Saber decidir, fazer, interpretar e redigir. Psiquilibrios Edições.

McAndrew, S., \& Warne, T. (2010). Coming out to talk about suicide: Gay men and suicidality. International Journal of Mental Health Nursing, 19, 92-101. https://doi.org/10.1111/j.1447-0349.2009.00644.x

McCain, N. L., \& Gramling, L. F. (1992). Living with dying: Coping with HIV disease. Issues in Mental Health Nursing, 13(3), 271-284. https://doi.org/10.3109/01612849209078778

McCann, E., Sharek, D., Higgins, A., Sheerin, F., \& Glacken, M. (2013). Lesbian, gay, bisexual and transgender older people in Ireland: Mental health issues. Aging and Mental Health, 17(3), 358-365. https://doi.org/10.1080/13607863.2012.751583

McParland, J., \& Camic, P. M. (2016). Psychosocial factors and ageing in older lesbian, gay 
and bisexual people: A systematic review of the literature. Journal of Clinical Nursing, 1-23. https://doi.org/10.1111/jocn.13251

Meyer, I. H. (1995). Minority stress and mental health in gay men. Journal of Health and Social Behavior, 36(1), 38-56. https://doi.org/10.2307/2137286

Meyer, I. H. (2003). Prejudice, social stress, and mental health in lesbian, gay, and bisexual populations: Conceptual issues and research evidence. Psychological Bulletin, 129(5), 674-697. https://doi.org/10.1037/o033-2909.129.5.674

Meyer, I. H., \& Northridge, M. E. (2007). The health of sexual minorities: Public health on lesbian, gay, bisexual and transgender populations. Nova Iorque: Springer.

Mills, E. J., Bärnighausen, T., \& Negin, J. (2012). HIV and aging - Preparing for the challenges ahead. New England Journal of Medicine, 366(14), 1270-1273. https://doi.org/10.1056/NEJMp1113643

Mills, T. C., Paul, J., Stall, R., Pollack, L., Canchola, J., Chang, Y. J., ... Catania, J. A. (2004). Distress and depression in men who have sex with men: The urban men's health study. American Journal of Psychiatry, 161, 278-285. https://doi.org/10.1176/appi.ajp.161.2.278

Morales, M. J., King, M. D., Hiler, H., Coopwood, M. S., \& Wayland, S. (2014). The greater St. Louis LGBT health and human services needs assessment: An examination of the silent and baby boom generations. Journal of Homosexuality, 61(1), 103-128. https://doi.org/10.1080/00918369.2013.835239

Nazaré, B., Pereira, M., \& Canavarro, M. C. (2017). Avaliação breve da psicossintomatologia: Análise fatorial confirmatória da versão portuguesa do Brief Symptom Inventory 18 (BSI 18). Analise Psicologica, 35(2), 213-230. https://doi.org/10.14417/ap.1287

Orel, N. A. (2014). Investigating the needs and concerns of lesbian, gay, bisexual, and transgender older adults: The use of qualitative and quantitative methodology. Journal of Homosexuality, 61(1), 53-78. https://doi.org/10.1080/oo918369.2013.835236

Pais-Ribeiro, J. L., Honrado, A., \& Leal, I. (2004). Contribuição para o estudo da adaptação portuguesa das Escalas de Ansiedade, Depressão e Stress (EADS) de 21 itens de Lovibond e Lovibond. Psicologia, Saúde e Doenças, 5(2), 229-239. 
Pechorro, P., Marôco, J., Poiares, C., \& Vieira, R. X. (2011). Validação da escala de autoestima de Rosenberg com adolescentes portugueses em contexto forense e escolar. Arquivos de Medicina, 25(5-6), 174-179.

Pereira, H. (2014). Condom use and HIV-related behaviors in Portuguese men who have sex with men: A study of sexual behavior and sexual pleasure. Journal of AIDS and Clinical Research, 5(4). https://doi.org/10.4172/2155-6113.1000294

Pereira, H., Caldeira, D., \& Monteiro, S. (2017). Perceptions of HIV-related stigma in Portugal among MSM with HIV infection and an undetectable viral load. Journal of the Association of Nurses in AIDS Care, 1-15. https://doi.org/10.1016/j.jana.2017.12.002

Pereira, H., de Vries, B., Serrano, J. P., Afonso, R. M., Esgalhado, G., \& Monteiro, S. (2019). Depression and quality of life in older gay and bisexual men in Spain and Portugal. International Journal of Aging and Human Development, 1-16. https://doi.org/10.1177/0091415019864600

Pereira, H., \& Monteiro, S. (2016). The role of political and legislative changes in the everyday lives of LGB individuals: The case of Portugal. Sexuality Research and Social Policy, 1-10. https://doi.org/10.1007/s13178-016-0261-x

Pereira, H., \& Rodrigues, P. (2015). Internalized homophobia and suicidal ideation among LGB youth. Journal of Psychiatry, 18(2), 1-6. https://doi.org/10.4172/Psychiatry.1000229

Porter, K. E., Brennan-Ing, M., Burr, J. A., Dugan, E., \& Karpiak, S. E. (2019). HIV stigma and older men's psychological well-being: Do coping resources differ for gay/bisexual and straight men? The Journals of Gerontology, 74(4), 685-693. https://doi.org/10.1093/geronb/gbx101

Quinton, D., \& Rutter, M. (1984). Parental psychiatric disorder: Effects on children. Psychological Medicine, 14, 853-880. https://doi.org/10.1017/Soo33291700019838

Rueda, S., Mitra, S., Chen, S., Gogolishvili, D., Globerman, J., Chambers, L., ... Rourke, S. B. (2016). Examining the associations between HIV-related stigma and health outcomes in people living with HIV/AIDS: A series of meta-analyses. BMJ Open, 6, 1-15. https://doi.org/10.1136/bmjopen-2016-011453

Semlyen, J., King, M., Varney, J., \& Hagger-Johnson, G. (2016). Sexual orientation and 
symptoms of common mental disorder or low wellbeing: Combined meta-analysis of 12 UK population health surveys. BMC Psychiatry, 16(67), 1-9. https://doi.org/10.1186/s12888-016-0767-z

Thomas, B. E., Rehman, F., Suryanarayanan, D., Josephine, K., Dilip, M., Dorairaj, V. S., \& Swaminathan, S. (2005). How stigmatizing is stigma in the life of people living with HIV: A study on HIV positive individuals from Chennai, South India. AIDS Care Psychological and Socio-Medical Aspects of AIDS/HIV, 17(7), 795-801. https://doi.org/10.1080/09540120500099936

Tomori, C., McFall, A. M., Srikrishnan, A. K., Mehta, S. H., Solomon, S. S., Anand, S., ... Celentano, D. D. (2016). Diverse rates of depression among men who have sex with men (MSM) across India: Insights from a multi-site mixed method study. AIDS and Behavior, 20, 304-316. https://doi.org/10.1007/s10461-015-1201-o

Vanable, P. A., Carey, M. P., Blair, D. C., \& Littlewood, R. A. (2006). Impact of HIV-related stigma on health behaviors and psychological adjustment among HIV-positive men and women. AIDS and Behavior, 10(5), 473-482. https://doi.org/10.1007/s104610o6-9099-1

Viana, R. D. S., \& Lourenço, L. M. (2017). Estudo qualitativo sobre a depressão e a ansiedade social na adolescência: Uma revisão bibliográfica. Psicologia.Pt, 1-16. https://doi.org/10.1117/12.692737

Wohl, A. R., Galvan, F. H., Carlos, J. A., Myers, H. F., Garland, W., Witt, M. D., ... George, S. (2013). A comparison of MSM stigma, HIV stigma and depression in HIV-positive latino and african american men who have sex with men (MSM). AIDS and Behavior, 17, 1454-1464. https://doi.org/10.1007/s10461-012-0385-9 
Mental Health, Resilience and HIV in Older Gay and Bisexual Men 


\section{Capítulo 2: Discussão Geral}

A presente dissertação de mestrado apresenta-se como um requisito para a obtenção do grau de mestre em Psicologia Clínica e da Saúde, com o objetivo de analisar os níveis de ansiedade, depressão, autoestima e resiliência numa amostra de homens gays e bissexuais mais velhos, tendo em conta o seu diagnóstico de VIH, sendo que não existem estudos que relacionem estas variáveis em Portugal, preenchendo-se, assim, uma lacuna que existe nesta área em específico. Neste estudo, procedeu-se à comparação dos níveis de ansiedade, depressão, autoestima e resiliência em homens gays e bissexuais mais velhos, com e sem diagnóstico de VIH, determinando o efeito preditor da resiliência e da autoestima nos sintomas depressivos e ansiosos da amostra. Desta forma, o presente estudo apresenta-se como pioneiro e inovador na sua tentativa de relacionar os diferentes conceitos em análise.

Os resultados do estudo vão contra o que era esperado inicialmente, demonstrando que ao contrário do que é comumente idealizado, os homens gays e bissexuais mais velhos revelam bons níveis de autoestima e níveis superiores de resiliência em comparação com a população em geral, demonstrando sintomas depressivos e ansiosos abaixo da média. Em comparação com os homens gays mais velhos, os homens bissexuais da amostra demonstraram níveis de autoestima e resiliência superiores e, consequentemente, níveis de depressão inferiores. Verificou-se, ainda, que quanto mais elevados os níveis de autoestima da amostra, maiores os seus níveis de resiliência e menores os valores de sintomas depressivos ou ansiosos. Da mesma forma, foi possível concluir que níveis inferiores de autoestima e resiliência se constituem como fatores preditores de sintomas depressivos nos homens mais velhos gays e bissexuais, bem como níveis inferiores de autoestima são preditores de sintomas ansiosos na mesma amostra.

Por se tratar de um estudo pioneiro, é fundamental que se continuem a desenvolver estudos nesta área, de forma a perceber até que ponto estes resultados podem ser generalizados para a comunidade gay e bissexual no geral, podendo ser ou não corroborados. Torna-se, ainda, fulcral o desenvolvimento de projetos nesta área que englobem amostras que possam ser comparáveis de modo fidedigno entre diversas orientações sexuais, incluindo a comunidade lésbica e heterossexual. Além disso, futuras investigações deverão ter a preocupação de identificar os problemas, as preocupações e as necessidades do processo de envelhecimento para os diversos grupos inseridos na comunidade LGBT. 
Portugal está, neste momento, a atravessar um processo de transformação, passando de um contexto repressivo para um contexto inclusivo da comunidade LGBT. Contudo, a sociedade ainda considera assuntos relacionados com homossexualidade e bissexualidade como um tabu, o que vem reforçar a invisibilidade destes indivíduos, sendo notável a escassez de estudos no que diz respeito à faixa etária mais velha numa comunidade tão específica como esta.

Tendo em conta a experiência de sofrimento psicológico e emocional dos indivíduos mais velhos pertencentes à comunidade LGBT ou com diagnóstico de VIH, é de considerar uma perspetiva de promoção da saúde destes mesmos sujeitos. Deve, assim, garantir-se um ambiente confortável quando estes acedem aos serviços de saúde, de forma a diminuir o medo que estes indivíduos sentem quando revelada a sua orientação sexual e/ou o seu diagnóstico. Recomenda-se, portanto, o desenvolvimento de serviços que se especializem em atender as necessidades específicas desta comunidade, particularmente nesta fase do ciclo de vida, de um modo inclusivo, desenvolvendo-se, ainda, estratégias para combater a discriminação nestes meios. Salienta-se, de igual modo, a necessidade de um maior foco por parte das equipas de triagem nos serviços de saúde ao nível da saúde mental destes indivíduos, fornecendo o apoio psicológico adequado.

A decisão de realizar a presente dissertação em formato de artigo permitiu demonstrar a evolução existente ao nível das competências de investigação na área da Psicologia, nomeadamente no que diz respeito à integração de informação com origem em diferentes fontes, à recolha e ao tratamento de dados estatísticos em programas informáticos, à análise crítica e interpretação dos resultados obtidos, culminando na comunicação escrita de toda a pesquisa realizada. De facto, e de acordo com o EuroPsy The European Certificate in Psychology (EFPA, 2013), espera-se que os estudantes que se encontram nesta fase do percurso académico desenvolvam algumas competências básicas no que diz respeito à investigação, realizando um projeto de investigação como o que aqui é apresentado, de modo a serem introduzidos às questões éticas das investigação em Psicologia, aplicando métodos básicos utilizados na área. 


\section{APÊNDICE}


Mental Health, Resilience and HIV in Older Gay and Bisexual Men 


\section{Apêndice Teórico}

\section{Saúde Mental}

De acordo com a Organização Mundial de Saúde (OMS), "a saúde é um estado de completo bem-estar físico, mental e social, e não apenas a ausência de doença ou enfermidade". Como tal, definem saúde mental como um estado de bem-estar no qual o indivíduo tem capacidades para enfrentar os stressores normais da vida, trabalha produtivamente e contribui para a comunidade (World Health Organization, 2018). A saúde mental é, assim, mais do que a ausência de perturbações mentais e encontra-se intimamente associada com a saúde física e com o comportamento (Herrman, et al., 2004, citados por Ribeiro et al., 2015), tendo como base a capacidade de ajustamento às transformações que ocorrem ao longo do ciclo de vida (Devereux, 1971, citado por N. Filho, Coelho, \& Peres, 1999).

Existem diversas emoções e estados que podem influenciar a saúde mental de um indivíduo, destacando-se entre elas a depressão e a ansiedade. Como tal, de seguida apresenta-se um pequeno enquadramento sobre estes termos, para uma melhor compreensão dos mesmos.

\subsection{Depressão}

No que concerne à depressão estima-se que globalmente esta atinja cerca de 350 milhões de pessoas, em qualquer idade (Tafet, 2019). É considerada uma perturbação do estado de humor, que afeta a capacidade cognitiva, psicomotora e vegetativa do sujeito, assim como a regulação dos seus instintos (S. Carvalho, Jara, \& Cunha, 2017; Porto, 1999).

Uma das causas para o surgimento de sintomas depressivos no ser humano consiste na experiência de acontecimentos traumáticos e adversos (S. Carvalho et al., 2017), que podem desencadear sentimentos exacerbados de tristeza. Se esta tristeza se prolongar de maneira indefinida, muito mais além da dimensão das circunstâncias que lhe deram origem e se, ao mesmo tempo, o indivíduo sentir e acreditar que nada do que possa fazer será suficiente para reverter essa situação, é muito provável que esteja a experienciar sintomas de depressão (Tafet, 2019).

O Manual de Diagnóstico e Estatística das Perturbações Mentais - $5^{\mathrm{a}}$ Edição (DSM5) (American Psychiatric Association, 2014) descreve quais os critérios a ter em atenção aquando do diagnóstico de depressão, neste caso da Perturbação Depressiva Major, citando: 
A. "Estão presentes 5 (ou mais) dos seguintes sintomas durante um período de 2 semanas consecutivas e representam uma alteração do funcionamento prévio; pelo menos, um dos sintomas é 1) humor deprimido ou 2) perda de prazer ou do interesse.

1. Humor deprimido durante a maior parte do dia, quase todos os dias, indicado ou pelo relato subjetivo (por exemplo, sente-se triste, vazio ou sem esperança) ou pela observação de outros (por exemplo, parece choroso).

2. Diminuição clara do interesse ou prazer em todas, ou quase todas, as atividades durante a maior parte do dia, quase todos os dias (indicado pelo relato subjetivo ou pela observação de outros).

3. Perda de peso, não estando a fazer dieta, ou aumento de peso significativos (por exemplo, uma alteração de mais de $5 \%$ do peso corporal num mês), ou diminuição ou aumento do apetite quase todos os dias.

4. Insónia ou hipersónia quase todos os dias.

5. Agitação ou lentificação psicomotoras quase todos os dias (observável pelos outros, não meramente pelo relato subjetivo de se sentir agitado ou lentificado).

6. Fadiga ou perda de energia quase todos os dias.

7. Sentimentos de desvalorização ou culpa excessiva ou inapropriada (que pode ser delirante) quase todos os dias (não meramente autocensura ou sentimentos de culpa por estar doente).

8. Diminuição da capacidade de pensar ou de concentração, ou indecisão, quase todos os dias (pelo relato subjetivo ou pela observação de outros).

9. Pensamentos de morte recorrentes (não apenas medo de morrer), ideação suicida recorrente sem plano específico ou tentativa de suicídio ou plano específico para cometer suicídio.

B. Os sintomas causam mal-estar clinicamente significativo ou défice social, ocupacional ou em qualquer outra área importante do funcionamento.

C. O episódio não é atribuível aos efeitos fisiológicos de uma substância ou a outra condição médica.

D. A ocorrência do episódio depressivo major não é mais bem explicado por perturbação esquizoafetiva, esquizofrenia, perturbação esquizofreniforme, perturbação delirante ou perturbações do espetro da esquizofrenia com outra especificação ou não especificada ou por outras perturbações psicóticas.

E. Nunca existiu um episódio maníaco ou um episódio hipomaníaco”.

Desta maneira, a depressão pode ser caracterizada pela proeminência de sentimentos de tristeza e vazio, pela perda da capacidade de experienciar prazer nas 
atividades em geral e pela redução do interesse, associada à sensação de fadiga e perda de energia (Porto, 1999). Estes sintomas persistem durante um certo tempo e perturbam significativamente o rendimento no trabalho, a vida familiar e pessoal do indivíduo, levando, consequentemente, a um sofrimento intenso (S. Carvalho et al., 2017).

Existem diversos instrumentos que podem ser utilizados pelos psicólogos, de forma a averiguar a presença de sintomas depressivos no indivíduo, incluindo o Inventário de Avaliação Clínica da Depressão (IACLIDE), o Center for Epidemiologic Studies Depression Scale (CES-D) e o Beck Depression Inventory-II (BDI-II).

O IACLIDE é um instrumento de autoavaliação que pretende medir a intensidade do quadro depressivo do indivíduo, identificando a sua presença e gravidade através de 23 questões, de formato tipo Likert de 5 pontos (A. Carvalho, 2012; Silva, 1999). Este inventário abrange quatro dimensões diferenciadas, particularmente alterações biológicas, sintomas cognitivos, modificação das relações interpessoais e supressão ou alteração do desempenho de tarefa. Estas estão associadas à relação que o indivíduo deprimido estabelece com o organismo, consigo próprio enquanto pessoa, com os outros e com o trabalho (A. Carvalho, 2012; Silva, 1999). As médias de cada uma das dimensões permitem compreender em que aspetos do quotidiano um indivíduo com depressão tem maior dificuldade (Silva, 1999). A pontuação total possibilita o estabelecimento dos graus de gravidade da depressão (Silva, 1999), sendo que quanto mais elevado o resultado mais grave será o quadro depressivo (A. Carvalho, 2012). Entre os 0-19 pontos considera-se que o indivíduo não se encontra deprimido, entre 20-34 admite-se depressão leve, 35-52 depressão moderada e, por último, depressão grave em pontuações iguais ou superiores a 53 (Silva, 1999).

Os primeiros estudos acerca do CES-D decorreram entre 1973 e 1977, sendo que este se trata de um questionário de autorresposta desenvolvido com o objetivo de avaliar a ocorrência de sintomatologia depressiva na população em geral, através de 20 questões (Gonçalves \& Fagulha, 2004). As respostas a cada item são dadas numa escala tipo Likert de 4 pontos, correspondente à avaliação do indivíduo da frequência do sintoma durante a última semana (Gonçalves \& Fagulha, 2004), sendo que numa pontuação entre 0-15 pontos considera-se que o sujeito não tem sintomas depressivos, entre os 16-24 assume-se depressão leve e a partir de 25 depressão moderada (Silva, 1999).

O BDI-II foi publicado pela primeira vez em 1996 de forma a avaliar os sintomas correspondentes aos critérios de diagnóstico para perturbações depressivas listadas, na altura, no DSM-IV, solicitando o sujeito que este relate a frequência dos sintomas depressivos na semana anterior à administração do instrumento. Este é composto por 21 
itens e pode ser administrado a indivíduos a partir dos 13 anos de idade, sendo que o seu resultado é obtido através da soma de todos os itens (Campos \& Gonçalves, 2011).

\subsection{Ansiedade}

A ansiedade é um sentimento vago e desagradável de medo e apreensão, caracterizado por tensão ou desconforto associado com a antecipação de perigo (Allen, Leonard, \& Swedo, 1995), afetando 3.5\% das pessoas mundialmente, sendo que essa percentagem tem vindo a aumentar todos os anos (Tafet, 2019). No entanto, não é possível explicar o conceito de ansiedade sem antes referir a emoção básica que lhe dá origem - o medo.

Salienta-se, assim, a diferença que existe entre sentir medo intenso, numa situação de perigo extremo, e o medo excessivo, desproporcionado em relação ao estímulo que o gerou. Tal dá origem à distinção entre outros dois tipos: o medo focado, ou seja, aquele que se pode sentir perante uma ameaça eminente, seja esta real ou imaginária; e o medo difuso, aquele que se experimenta de forma generalizada e inespecífica e sobre o qual é difícil identificar a ameaça concreta que o suscita. É este último que se associa à ansiedade (Tafet, 2019).

O DSM-5 (American Psychiatric Association, 2014) explicita quais os critérios a ter em atenção para o diagnóstico de ansiedade, nomeadamente Perturbação de Ansiedade Generalizada, passando a citar:

A. "Ansiedade e preocupação excessivas (apreensão expectante) que ocorrem em mais de metade dos dias durante pelo menos seis meses, sobre vários acontecimentos ou atividades (tais como desempenho laboral ou escolar).

B. O indivíduo tem dificuldade em controlar a preocupação.

C. A ansiedade e a preocupação estão associadas com 3 (ou mais) dos 6 sintomas seguintes (com pelo menos alguns sintomas presentes em mais de metade dos dias durante 6 meses):

1. Agitação, nervosismo ou tensão interior.

2. Fadiga fácil.

3. Dificuldades de concentração ou mente vazia.

4. Irritabilidade.

5. Tensão muscular.

6. Perturbações do sono (dificuldade em adormecer ou permanecer a dormir, ou sono insatisfatório). 
D. A ansiedade, preocupação ou sintomas físicos causam mal-estar clinicamente significativo ou défice no funcionamento social, ocupacional ou noutras áreas importantes do funcionamento.

E. A perturbação não é atribuível a efeitos fisiológicos de uma substância (por exemplo, droga de abuso, medicação) ou outra condição médica (por exemplo, hipertiroidismo).

F. A perturbação não é mais bem explicada por outra perturbação mental (por exemplo, ansiedade ou preocupação pela possibilidade de ter ataques de pânico na perturbação de pânico, avaliação negativa na perturbação de ansiedade social [fobia social], contaminação ou outras obsessões na perturbação obsessivacompulsiva, separação das figuras de vinculação na perturbação de ansiedade de separação, recordações de acontecimentos traumáticos na perturbação de stress pós-traumático, ganho de peso na anorexia nervosa, queixas físicas na perturbação de sintomas somáticos, defeitos na aparência percebida na perturbação dismórfica corporal, ter uma doença grave na perturbação de ansiedade de doença, ou conteúdo de crenças delirantes na esquizofrenia ou perturbação delirante)".

Podemos entender, então, a ansiedade como uma experiência emocional determinada por uma sensação de medo difuso e inespecífico causado por uma possível ameaça (Tafet, 2019). Esta é reconhecida como patológica quando se torna exagerada, desproporcional relativamente ao estímulo, interferindo com a qualidade de vida do indivíduo, com o seu conforto emocional ou com o seu desempenho diário (Allen et al., 1995).

Entre os sintomas de ansiedade mais característicos destaca-se: o aumento do ritmo cardíaco, percebido sob a forma de palpitações; o aumento da frequência respiratória, que dá a sensação de uma certa falta de ar ou de uma verdadeira dificuldade em respirar; alterações no sistema digestivo, percebidas como dores abdominais difusas, náuseas e, mais comumente, diarreia (Tafet, 2019). Estes sintomas quando presentes diariamente na vida do indivíduo causam desconforto e interferem no seu bem-estar, tanto físico quanto emocional.

Existem várias técnicas que podem ser empregadas pelos psicólogos, de forma a averiguar a presença de sintomas ansiosos no indivíduo. Contudo na revisão de bibliografia apenas foram encontrados instrumentos que avaliam a ansiedade como uma das suas dimensões, sendo que será essa a dimensão descrita já de seguida. Este é o caso 
de instrumentos como o Symptom Checklist-90-R (SCL-90-R) e das Escalas de Ansiedade, Depressão e Stress (EADS).

A primeira versão do SCL-90-R surgiu em 1973, tratando-se de um inventário clínico de autoavaliação de sintomas de desajustamento emocional constituído por 90 itens, em formato tipo Likert de o a 4 pontos (A. Carvalho, 2012; Chincalece, 2009). Os seus itens dizem respeito a problemas psicológicos ou queixas sintomáticas, com a intenção de obter uma medição do estado de sintomas no momento presente (Marques, 2003). O SCL-90-R avalia a psicopatologia do sujeito de acordo com nove dimensões de sintomas - somatização, obsessão-compulsão, sensibilidade interpessoal, depressão, ansiedade, hostilidade, ansiedade fóbica, ideação paranóide, psicoticismo e uma escala adicional - e três índices globais - índice de gravidade global (GSI), índice de sintomas positivos (PSDI) e número de sintomas positivos (PST). A escala de ansiedade é composta por 10 itens e integra um conjunto de sintomas e comportamentos associados à ansiedade manifesta, nomeadamente inquietude, nervosismo, tensão e sentimentos de dissociação (Chincalece, 2009). Além disso, encontram-se, ainda, presentes alguns sintomas de ansiedade generalizada e de ataques de pânico (A. Carvalho, 2012). Os resultados brutos deste inventário são obtidos através da soma dos valores das respostas dadas em cada item, sendo que o somatório de cada dimensão deve ser dividido pelo número de itens dessa mesma dimensão. Os resultados são significativos quando superiores a 2,3 (Chincalece, 2009).

A Escala de Ansiedade, Depressão e Stress (EADS) propõe-se a abranger o máximo de sintomas de ansiedade e depressão, fornecendo uma discriminação máxima entre estes dois construtos (Pais-Ribeiro, Honrado, \& Leal, 2004; Pinto, Martins, Pinheiro, \& Oliveira, 2015). Esta assume as perturbações psicológicas segundo um modelo dimensional e, como tal, avoca que as diferenças na depressão, ansiedade e stress experienciadas pelos indivíduos são essencialmente ao nível de diferenças de grau (PaisRibeiro et al., 2004). Como tal, pretende avaliar os sintomas associados à ansiedade, depressão e stress em jovens adultos e adultos português (Pinto et al., 2015), sendo administrada a indivíduos com idade superior a 17 anos (Pais-Ribeiro et al., 2004). A EADS é constituída por 21 itens, numa escala tipo Likert de 4 pontos, em que os indivíduos avaliam a extensão em que experimentam cada sintoma durante a última semana (Pais-Ribeiro et al., 2004; Pinto et al., 2015). A subescala ansiedade enfatiza a ligação entre estados persistentes de ansiedade e as respostas intensas de medo e é constituída por questões acerca de excitação do sistema autónomo, efeitos músculos esqueléticos, ansiedade situacional e experiências subjetivas de ansiedade (Pais-Ribeiro et al., 2004; Pinto et al., 2015). A cotação é obtida através da soma dos resultados dos itens, 
com um mínimo de o e um máximo de 21 para cada subescala, sendo que notas mais elevadas correspondem a estados afetivos mais negativos (Pinto et al., 2015).

\section{Autoestima}

O conceito de autoestima foi concebido por Stanley Standal, na década de 1950 (Scartezini, Rocha, \& Pires, 2013), apesar de os primeiros estudos sobre esta terem sido realizados anos antes, por William James (James, 2012, citado por Schultheisz \& Aprile, 2013), defendendo que a autoestima tem por base os atributos de cada indivíduo (M. Sousa, 2015).

A autoestima é considerada uma das necessidades psicológicas fundamentais para o ser humano (Guerreiro, 2011), uma vez que interfere nas suas condições afetivas, sociais e psicológicas (Moreno \& Roda, 2003). Desta forma, é uma das premissas mais importantes para uma vida mais satisfatória (Branden, 2009), apresentando-se como um determinante de bem-estar, fundamental na vida do indivíduo (Baumeister, Campbell, Krueger, \& Vohs, 2003; Dutton \& Brown, 1997). Esta tem a função de fazer corresponder a visão que os outros têm do sujeito àquilo que ele é verdadeiramente, tendo por base os padrões culturais da sociedade onde este está inserido (Guerreiro, 2011), assumindo-se como um construto interno e pessoal influenciado pelo contexto social e cultural em que o indivíduo se insere (Schultheisz \& Aprile, 2013). A autoestima encontra-se, assim, associada à forma como o indivíduo interpreta o feedback dos outros, sendo que quando o sujeito acredita em si mesmo e possui uma autoestima positiva, tolera melhor as críticas dos outros (M. Sousa, 2015).

A autoestima trata-se de um conjunto de pensamentos e sentimentos referentes a si mesmo, com tendência para ser estável ao longo do tempo e em diferentes contextos na vida adulta (Hutz \& Zanon, 2011). Esta pode ser explicada como a componente avaliativa e valorativa da pessoa acerca de si própria (Guerreiro, 2011), compreendida como a distância que existe entre o que o indivíduo é e o que gostaria de ser, e o que este sente acerca dessa mesma distância (Lawrence, 2006, citado por Cremers-Laurent, 2015). Quanto menor for a distância entre a realidade do ser humano e as suas aspirações e desejos, maior será a sua autoestima (Coll et al., 2004, citados por Cremers-Laurent, 2015).

A autoestima é, assim, um juízo pessoal, que estabelece uma comparação entre o que cada sujeito é e o que deseja ser (Duclos, 2006, citado por Cremers-Laurent, 2015). É a razão entre o sucesso e as aspirações pessoais do indivíduo, construída ao longo do seu 
desenvolvimento (Guerreiro, 2011), sendo que pode dividir-se em: autoestima perante si mesmo, pela qual o indivíduo orienta o seu comportamento tendo por base o conhecimento que tem de si próprio; e, autoestima como avaliação pessoal, relacionada com as perceções, pensamentos, avaliações e sentimentos que o sujeito dirige a si (M. Sousa, 2015).

Branden (2009) refere que a autoestima é composta, ainda, por dois componentes: o sentimento de competência pessoal e o sentimento de valor pessoal, refletindo o julgamento implícito da capacidade do indivíduo para lidar com os desafios da vida. Esta indica a forma como o indivíduo se percebe em relação a determinado aspeto e a importância que este tem para si, sendo que o seu processo de desenvolvimento ocorre desde a infância, consolidando-se ao longo do tempo (Guilhardi, 2002; J. Guimarães, 2012; Scartezini et al., 2013). Para que este desenvolvimento ocorra de forma bemsucedida, é necessário que o sujeito tenha equilíbrio emocional e cognitivo, boa saúde mental e relações satisfatórias, assim como uma autoestima positiva (Quiles \& Espada, 2007, citados por J. Guimarães, 2012), sendo que pessoas com abundância de carinho e aprovação por parte do seu contexto social, particularmente dos seus entes mais significativos, estão propensas a desenvolver níveis de autoestima mais elevados (Branden, 2009).

Quanto maior a autoestima do sujeito, melhor preparado este se encontra para lidar com as adversidades do quotidiano, maior a probabilidade de este obter sucesso e maior a possibilidade de manter relacionamentos saudáveis (Branden, 2009), particularidades relevantes para o equilíbrio da vida pessoal, profissional e social do ser humano (Quiles \& Espada, 2007, citados por J. Guimarães, 2012). Além disso, indivíduos com índices elevados de autoestima sentem menos sofrimento emocional quando fracassam, em comparação com sujeitos com baixa autoestima, uma vez que os primeiros pensam em si de forma mais positiva, diferenciando as suas reações cognitivas e emocionais frente ao fracasso (Dutton \& Brown, 1997). Contudo, quando tal não acontece e ocorrem vulnerabilidades ao nível da autoestima podem surgir diversas perturbações mentais (Guerreiro, 2011), nomeadamente ansiedade, depressão, abuso de álcool e/ou drogas, disfunções sexuais e suicídio (Branden, 2009; J. Guimarães, 2012).

\section{Resiliência}

O termo resiliência tem sido utilizado pela Física e Engenharia, ciências das quais emerge, como sendo a capacidade de um material absorver energia sem sofrer qualquer deformação permanente, recuperando a sua forma inicial (Sordi, Hauck, \& Manfro, 2011; 
Yunes, 2003). Este conceito foi, depois, transposto para a área da Psicologia, sendo que o seu estudo é relativamente recente, sendo apresentado de diversas formas por diferentes autores. Deste modo, não existe ainda um consenso sobre a definição de resiliência, sendo que a sua conceitualização pode ser distinta (Herrman et al., 2011).

O ser humano é dotado de um grande potencial para resistir às adversidades da vida e para se adaptar quando necessário. Como tal, os estudos sobre resiliência afastam o campo de investigação da saúde mental de um modelo com base no deficit e direcionamno para a inclusão de modelos com foco na competência dos indivíduos (Southwick, Bonanno, Masten, Panter-Brick, \& Yehuda, 2014).

A introdução deste termo no campo das ciências da saúde ocorreu na década de 1970 (Souza \& Cerveny, 2006), assumindo-se como um processo dinâmico que pode variar consoante o contexto (Sordi et al., 2011). Assim, a resiliência pode ser específica ao contexto e ao tempo, não estando, portanto, presente em todos os domínios da vida do ser humano (Herrman et al., 2011), sendo passível de se modificar ao longo da vida, conforme as circunstâncias passadas e presentes (Sordi et al., 2011). A resiliência pode ser, então, percebida como uma interação dinâmica entre características individuais e a complexidade do contexto social (Rooke \& Pereira-Silva, 2012), tendo em conta diferentes fatores de proteção e acontecimentos de vida (Poletto \& Koller, 2008), com a função de desenvolver a capacidade humana para enfrentar, vencer e sair fortalecido de situações adversas (Melillo, 2005, citado por J. Filho, 2014).

A American Psychological Association (APA) define resiliência como o "processo de adaptação diante das adversidades, traumas, tragédias, ameaças ou fontes significativas de stress" (American Psychological Association, 2020), considerando a capacidade do ser humano para crescer frente às experiências adversas da vida (Southwick et al., 2014). Este termo diz, assim, respeito à capacidade de um sistema, dinâmico, se adaptar com sucesso a distúrbios que ameaçam a sua viabilidade, função ou desenvolvimento (Masten, 2014),

A resiliência pode ser vista, ainda, como um modo de aproveitar recursos que sustentem o bem-estar do indivíduo (Panter-Brick \& Leckman, 2013), abrangendo uma reintegração do eu. Tal inclui um esforço consciente para avançar de uma forma positiva e perspicaz, como resultado de aprendizagens retiradas de uma experiência adversa. A este processo encontra-se associada a capacidade de aplicar uma variedade de estratégias de coping de forma flexível, utilizando o feedback para ajustar essas mesmas estratégias (Southwick et al., 2014). 
A resiliência implica, assim, duas componentes: a adversidade significativa, isto é, o coping de uma situação adversa, tendo em conta o significado específico que o indivíduo, família, organização, sociedade ou cultura lhe atribui; e a adaptação positiva, ou seja, a forma como estes reestruturam a sua vida a partir da situação, mesmo que esta influencie de forma negativa a saúde ou o desenvolvimento (Feder, 2019; J. Filho, 2014; Southwick et al., 2014). A resiliência mede-se, assim, através destes dois elementos (Feder, 2019), tendo em conta a capacidade de o sujeito se reorganizar frente a uma situação adversa, sendo transformado por ela, de forma a adaptar-se à sua realidade externa (Pinheiro, 2004; Sordi et al., 2011; Yunes, 2003).

A investigação mais recente acerca da resiliência tem como foco a contribuição dos sistemas, nomeadamente da família, grupos ou da comunidade, para ajudar as pessoas a lidar com as contrariedades da vida. Assim, assume-se que existem fatores e sistemas que podem contribuir para um processo dinâmico e interativo que, consequentemente, aumenta os níveis de resiliência dos indivíduos (Herrman et al., 2011). Estes fatores positivos podem variar consoante cada indivíduo, dependendo de fatores como a personalidade, desafios específicos, recursos disponíveis e o meio ambiente (Southwick et al., 2014).

Desta forma, os determinantes positivos da resiliência integram uma série de fatores biológicos, psicológicos, sociais e culturais que interagem entre si para determinar como o indivíduo reage às experiências stressantes (Southwick et al., 2014). Estes podem ajudar a promover o bem-estar social e emocional dos indivíduos (Correia, 2018) e, como tal, desenvolver a sua resiliência. Alguns destes fatores dizem respeito à inteligência, estabilidade emocional, estratégias de coping adequadas, autonomia, controlo, atenção e predisposição genética (Pesce, Assis, Santos, \& Oliveira, 2004); autoestima e otimismo (Herrman et al., 2011; Poletto \& Koller, 2008); relacionamentos saudáveis, capacidade de regulação emocional, autoconsciência, capacidade de visualizar o futuro, mecanismos de motivação que levam o sujeito a aprender, crescer e adaptar-se ao contexto (Joseph \& Linley, 2006; Southwick et al., 2014); sociabilidade, criatividade na resolução de problemas, e noção de autonomia (Yunes, 2003). Ademais, a personalidade, o locus de controlo interno e a autoeficácia têm sido, de igual forma, associados à resiliência (Herrman et al., 2011), assim como a flexibilidade cognitiva, o coping ativo, a esperança e a capacidade de adaptabilidade (Joseph \& Linley, 2006).

O indivíduo resiliente é, assim, aquele que tem a capacidade para reconhecer a dor, perceber o seu sentido e tolerá-la, de forma a resolver os conflitos de modo construtivo (Flach, 1991, citado por Pinheiro, 2004), sendo possível que esta habilidade seja adquirida 
quando o sujeito evita uma situação significativa de stress, frequente ou prolongado, ou quando os efeitos dessa situação são mediados por fontes de suporte (Herrman et al., 2011). Uma destas fontes de suporte mais fulcral para o ser humano advém dos seus relacionamentos familiares, de amizade, com professores ou outras pessoas significativas para o sujeito (Herrman et al., 2011; Southwick et al., 2014). O processo de resiliência dependerá, assim, das relações funcionais e das interações saudáveis que o indivíduo tenha estabelecido com o ambiente social, cultural, económico e biofísico imediato (Almedom, 2015; Pinheiro, 2004).

\section{Sexualidade e Orientação Sexual}

\subsection{Desenvolvimento da Identidade Sexual}

A orientação sexual diz respeito à atração emocional, afetiva ou sexual por indivíduos (Crenitte, Miguel, \& Filho, 2019), sendo esta a forma pela qual as pessoas sentem e experimentam os seus desejos (Louro, 2000, citado por Gross \& Pinhal de Carlos, 2015). A orientação sexual pode ser muito fluída em determinados momentos da vida e mais fixa noutros (Bilodeau \& Renn, 2005), compreendendo fatores como a atração sexual, comportamentos, fantasias e preferências emocionais e sociais (Shively \& De Cecco, 1977).

A construção de uma identidade regida por uma orientação não-heterossexual é um processo repleto de conflitos internos e externos ao sujeito, que deverão ser resolvidos ( $\mathrm{F}$. Almeida, 2011; Bilodeau \& Renn, 2005), para que o indivíduo atinja um bem-estar físico e mental. Este processo é um fenómeno central, que implica transformações intra e interpessoais e que leva ao reconhecimento da identidade sexual do sujeito (Davies, 1996, citado por Pereira \& Leal, 2005), sendo denominado por processo de coming out (Bilodeau \& Renn, 2005).

Alguns teóricos da área indicam que a primeira fase do coming out é caracterizada por uma confusão identitária, em que o sujeito emprega diversas estratégias de coping para reprimir os seus sentimentos, sendo que tal poderá ter consequências negativas, tanto ao nível da saúde mental, como emocional do indivíduo (Bilodeau \& Renn, 2005). Para muitos sujeitos, o passo seguinte passa pela interiorização da sua orientação sexual e, consequentemente, pelo facto de pertencerem a uma minoria que é discriminada pelos outros (Simões, 2004, citado por F. Almeida, 2011). Nesta fase, pode iniciar-se um período de experimentação com a homossexualidade, tanto em termos emocionais como comportamentais (Bilodeau \& Renn, 2005). Com a aceitação dos seus sentimentos não- 
heterossexuais, surge no indivíduo um sentido de identidade, integrado internamente e visto como um aspeto positivo sobre si mesmo (Bilodeau \& Renn, 2005), no qual sentimentos de raiva e frustração são substituídos pela aceitação pessoal e pública da sua identidade (Simões, 2004, citado por F. Almeida, 2011). No que concerne aos homens bissexuais, o processo de coming out pode desenvolver-se de forma um pouco diferente, na medida em que alguns atingem a sua identidade bissexual após se autorrotularem como gays (Bilodeau \& Renn, 2005).

Atualmente, em Portugal, o processo previamente descrito é limitado por muitas tensões, particularmente na decisão de assumir ou não a sua orientação sexual (F. Almeida, 2011), uma vez que nem sempre é bem aceite pela sociedade já que esta se rege por um modelo de heteronormatividade e, como tal, orientações sexuais divergentes são culpabilizadas (Gross \& Pinhal de Carlos, 2015), por não seguirem o modelo tido como regra. Desta forma, torna-se importante fazer um enquadramento das situações às quais estes indivíduos estão sujeitos, para melhor compreendermos a sua situação e o que ela implica em termos mentais.

\subsection{Discriminação, Preconceito e Estigmatização}

As atitudes de discriminação e estigmatização para com indivíduos que fogem à heteronormatividade datam de há muitos anos atrás, desde a época pré-moderna, na qual os homens que mantinham relações sexuais entre si eram perseguidos em alguns países da Europa, sendo este tipo de prática sexual considerado um ato criminoso (Toledo \& Pinafi, 2012).

Anos mais tarde, no século XIX, a comunidade médica classificou a homossexualidade como uma patologia mental, sendo estes indivíduos tratados como portadores de uma perturbação mental (Duarte, 2014; Terto Jr., 2002). Também a psicologia contribuiu para a marginalização dos sujeitos homossexuais, considerando a homossexualidade como uma anormalidade do comportamento, uma inversão sexual (A. Guimarães, 2009), assumindo que poderia ajudar estes indivíduos nas suas tentativas de se tornarem heterossexuais (Herek, 2007). Somente na década de 1970, a homossexualidade foi retirada da lista oficial do Manual de Diagnóstico e Estatística de Perturbações Mentais - $3^{\text {a }}$ Edição (DSM-III) (Duarte, 2014) e, na década de 1990, da lista oficial da OMS (Matias, 2007), emergindo na mesma altura o termo gay como forma de eliminar o valor psiquiátrico por trás da palavra "homossexual” (A. Guimarães, 2009).

Hoje é possível perceber que as crenças por trás das repressões políticas, médicas e religiosas se baseavam em suposições sem fundamento e que a homossexualidade é uma 
variante normal da expressão sexual humana (Herek, 2007). Contudo, ainda existe uma grande variedade na forma como as relações homossexuais e bissexuais são vistas pela sociedade (F. Almeida, 2011).

Os homens gays e bissexuais continuam, atualmente, numa situação de particular vulnerabilidade, na medida em que ao romperem com o modelo de heteronormatividade imposto na sociedade, sofrem de preconceito, discriminação e intolerância (Duarte, 2014; Gross \& Pinhal de Carlos, 2015; Herek, 2007) e passam por situações de aversão e ódio, resultantes do desprezo direcionado aos mesmos (Antunes, 2017; K. Sousa, 2016). Estas atitudes, de exclusão para com as pessoas que não se regem pelos ideais de heteronormatividade, são designadas por homofobia (Toledo \& Pinafi, 2012), sendo que esta atua sobre todos os que sofrem sob a norma heterossexual: pessoas lésbicas, gays, bissexuais, travestis, transexuais e todos os que vivenciam relações afetivo-sexuais com pessoas do mesmo sexo (Antunes, 2017; Toledo \& Pinafi, 2012). Particularmente, no que concerne aos homens bissexuais, estes são alvo de um estigma que os classifica como indivíduos com um certo grau de confusão identitária ou que os assume como cobardes que não se conseguem assumir enquanto homens gays (Clarke et al., 2010, citados por Costa, Pereira, Oliveira, \& Nogueira, 2010).

É comum que, ainda antes de os homens gays e bissexuais se aperceberem da sua própria orientação sexual, assimilem atitudes anti-homossexuais que advém da sociedade onde estão inseridos. Desta maneira, quando estes se apercebem da sua orientação sexual começam desde início a aplicar atitudes negativas a si mesmos e, é nesse momento, que os efeitos psicológicos da homofobia começam a surgir (Meyer, 1995). Assim, situações de homofobia não ocorrem exclusivamente de heterossexuais para com homossexuais ou bissexuais, mas podem também manifestar-se entre estes e os seus pares (Toledo \& Pinafi, 2012), dado que a maioria dos indivíduos, quando confrontados com a discriminação e estigma dos quais são alvo, acabam por interpretar os papéis e as condutas que a sociedade onde estão inseridos espera deles (Castañeda, 2007, citado por Toledo \& Pinafi, 2012).

A comunidade LGBT, hoje em dia, experiencia um panorama diversificado de mudanças sociais relacionadas com a conquista dos seus direitos, assim como a desconstrução de tabus (Santos, Araújo, \& Negreiros, 2018). Em Portugal, para tentar proteger os homens gays e bissexuais de situações como as anteriormente referidas, foi instituído no Código de Trabalho um artigo que refere a proibição da discriminação com base na orientação sexual no acesso ao emprego (Decreto Lei n.o 99/2003 de 27 de agosto da Assembleia da República, 2003) e foi aprovado o casamento civil entre pessoas do 
mesmo sexo (Decreto Lei n.o 9/2010 de 31 de maio da Assembleia da República, 2010). Contudo, o que a realidade nos diz é que, quanto mais se avança nos direitos humanos LGBT, também mais se apresentam as formas discriminatórias e violentas, devido ao aumento da visibilidade destes sujeitos (Duarte, n.d.).

As situações de discriminação e violência para com indivíduos pertencentes a esta minoria sexual interferem com os seus resultados ao nível da saúde mental. Desta forma, é apresentado de seguida um modelo explicativo - modelo de stress de minorias - sobre as diferenças que existem ao nível da saúde mental tendo em consideração estas situações de estigma.

\subsection{Modelo de Stress de Minorias}

O modelo de stress de minorias de Meyer (1995; 2003) analisa as formas pelas quais os stressores vivenciados por indivíduos pertencentes a uma minoria se podem relacionar com as disparidades existentes ao nível da saúde mental (Meyer, 2003), fornecendo uma estrutura fundamental para a compreensão das mesmas.

Este modelo tem como foco a incongruência que existe entre a cultura e as necessidades do indivíduo pertencente à minoria e a estrutura da sociedade onde este está inserido (Meyer, 1995). Assim, assume-se que quando o indivíduo pertence a uma minoria, neste caso particular minoria sexual, numa sociedade discriminatória, o conflito entre esse indivíduo e a cultura dominante pode ser pesado e o resultado do stress significativo (Meyer, 1995). Este stress pode derivar do estatuto minoritário do indivíduo (Brooks, 1981, citado por Meyer, 1995), uma vez que estes se encontram sujeitos a um stress crónico relacionado com a discriminação e a estigmatização de que sofrem (Meyer, 1995). Como tal, Meyer (1995) assume que o stress de minorias pode levar, consequentemente, a resultados negativos ao nível da saúde mental.

O modelo de stress de minorias afirma, então, que as minorias sofrem de stressores crónicos específicos e distintos, através de dois tipos de mecanismos - stressores externos e stressores internos, que abrangem as atitudes negativas e estereótipos internalizados em relação ao status minoritário, as expectativas de estigma e os eventos prejudiciais reais (Meyer, 1995; 2003). Deste modo, os stressores crónicos existentes na vida dos indivíduos podem ser compreendidos como: a) estigma promulgado, no que diz respeito a atos públicos de discriminação e interações interpessoais de vitimização ou preconceito; b) estigma percebido, que inclui as expectativas de rejeição sobre a probabilidade de o estigma ser promulgado em diversas situações e circunstâncias; c) estigma internalizado, no qual um indivíduo aceita as crenças, visões e sentimentos negativos dirigidos a si, 
também designada, no caso, por homofobia internalizada (Herek, 2007; Meyer, 1995; 2003). O estigma internalizado trata-se, assim, da aceitação pessoal do estigma sexual como parte do sistema de valores do próprio indivíduo e do seu autoconceito. Deste modo, o indivíduo aceita a avaliação negativa da sociedade sobre a sua homo/bissexualidade e, consequentemente, revela atitudes negativas em relação a si próprio e em relação aos seus desejos (Herek, 2007).

No entanto, Meyer (2003) refere, ainda, no seu modelo, alguns fatores que têm o potencial de amenizar as experiências de stress de minorias, agindo como fatores protetores, nomeadamente o suporte social e a utilização de estratégias de coping adequadas (Meyer, 2003). Deste modo, os indivíduos que se envolvem ativamente na comunidade LGBT são capazes de atingir fatores de resiliência, nomeadamente ao nível de apoio social e emocional por parte de pessoas com identidade e experiências compartilhadas (Testa, Habarth, Peta, Balsam, \& Bockting, 2015). Este stress pode ser, então, enfrentado criando oportunidades de apoio social, afirmando e validando a cultura e os valores das minorias, e permitindo a reavaliação e desvalorização dos valores estigmatizadores da cultura dominante (Crocker \& Major, 1989; Garnets \& Kimmel, 1991; Jones et al., 1984; Shade, 1990; Smith \& Siegel, 1985; Thoits, 1985, citados por Meyer, 1995).

O modelo acima referido encontra-se sumariado na figura a seguir apresentada.

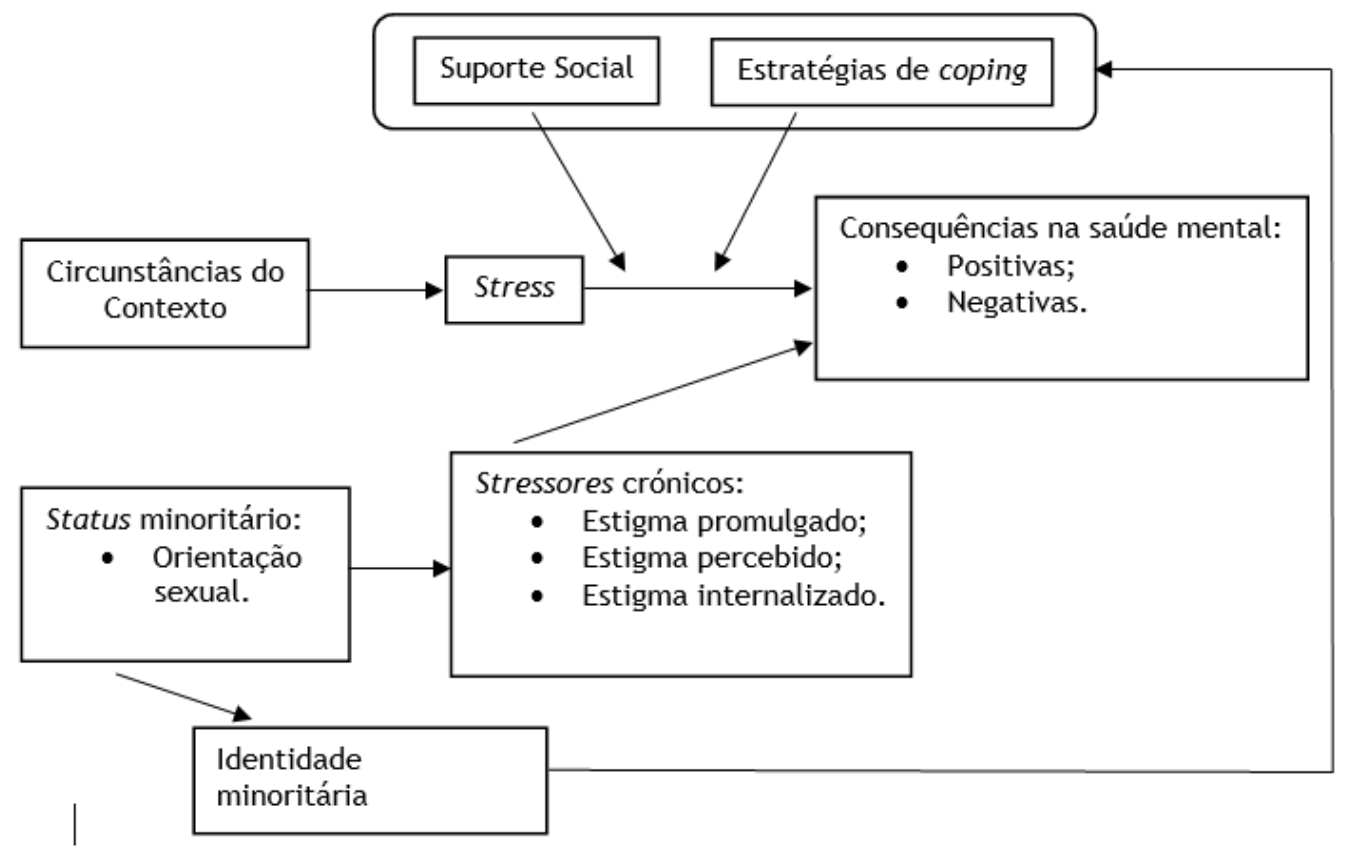

Figura 1: Modelo de stress de minorias 


\subsection{O Processo de Envelhecimento e Orientação Sexual}

O processo de envelhecimento de qualquer ser humano é caracterizado por diversas mudanças biopsicossociais (Santos et al., 2018), sendo que com os avanços da medicina e da tecnologia este processo se tornou mais saudável e com melhor qualidade de vida (H. Andrade, Silva, \& Santos, 2010). Contudo, coloca-se, ainda, como um desafio à sociedade, devido ao seu caráter social e à desvalorização em torno desta fase de desenvolvimento do ser humano (Crenitte et al., 2019), sendo que as pessoas com idade mais avançada, tal como as pessoas LGBT, experienciam atitudes e estereótipos por parte da sociedade onde estão inseridas (Santos et al., 2018).

No que diz respeito à sexualidade em indivíduos com idade mais avançada, esta é considerada inexistente por parte da restante sociedade, pelo facto de se associar ao processo de envelhecimento determinadas perdas funcionais (Santos et al., 2018). Além disso, na sociedade dos dias de hoje existe, ainda, uma conotação universal e generalizadora da heterossexualidade determinada pela identidade social do indivíduo mais velho (Antunes, 2017), dificultando a visibilidade da multiplicidade e complexidade existentes nas diversas realidades da população mais velha (Crenitte et al., 2019). Contudo, a população mais velha é, também, composta por pessoas LGBT e este número tem vindo a aumentar nas últimas décadas, devido ao aumento da longevidade e da esperança de vida (Araújo, 2016). Como tal, é necessário perceber quais as diferenças que estão inerentes ao processo de envelhecimento em indivíduos LGBT, neste caso específico, em homens gays e bissexuais.

Devido à repressão que se fazia sentir há uns anos, é possível assumir que os indivíduos gays e bissexuais mais velhos dos dias de hoje, vivenciaram uma juventude marcada por essas mesmas situações (Santos et al., 2018). Como tal, passaram a maior parte da sua vida a negar a sua orientação sexual e, ao aproximarem-se de uma idade mais avançada podem, de igual modo, negar o processo de envelhecimento, de forma a evitar os estereótipos associados à idade enquanto parte da comunidade LGBT (Santos et al., 2018). Estes homens assumem este processo como algo assustador, devido à imagem de solidão associada a esta fase da vida (Henning, 2017).

O processo de envelhecimento em indivíduos gays e bissexuais encontra-se, assim, associado a diversas representações sociais no que diz respeito à solidão, perdas sociais e físicas, invisibilidade, preconceito devido ao avanço da idade, depressão, redução ou ausência das redes de suporte social (Henning, 2017), sendo marcado por uma tríade de dificuldades, particularmente ao nível da aceitação para consigo, os outros e o medo do futuro (Santos, Araújo, Negreiros, \& Cerqueira-Santos, 2018). 
Embora os indivíduos mais velhos gays e bissexuais passem por situações de stress semelhantes a indivíduos com uma idade mais avançada heterossexuais, os primeiros enfrentam, ainda, situações de estigma relativamente à sua orientação sexual e discriminação associado à idade (Lima, 2013; Mota, 2009; Pope, Wierzalis, Barret, \& Rankins, 2007). Como tal, um dos principais fatores que diferencia o processo de envelhecimento em indivíduos heterossexuais e homo/bissexuais é a experiência associada entre o estigma de velhice e o estigma da homossexualidade. Tal combinação de estigmas gera cenários desafiadores e problemáticos para pessoas pertencentes à comunidade LGBT. Portanto, o que diferencia o processo de envelhecimento entre estes dois grupos não passa propriamente pela orientação sexual em si, mas pelas experiências de preconceito, discriminação e violência experienciadas ao longo da vida (Henning, 2017).

Contudo, um estudo de Araújo, Silva e Santos (2017) demonstra que indivíduos mais velhos possuem resiliência para enfrentar, de forma positiva, os aspetos negativos do processo de envelhecimento. Tal indica que existem marcadores como homossexualidade e velhice que podem promover recursos sociais adicionais, um elemento vantajoso no seu processo de envelhecimento (Henning, 2017), sendo que a superação e a atribuição de novos significados aos estigmas sentidos por estes indivíduos ao longo da vida são essenciais para garantir um envelhecimento bem-sucedido, com relações afetivas e sociais que garantam redes de suporte nesta etapa da vida (Pereira \& Leal, 2012).

Num estudo de Pereira, et al. (2017), realizado em Portugal, muitos homens gays e bissexuais mais velhos enfatizaram que a aceitação total das suas características pessoais, especialmente a sua homossexualidade ou bissexualidade, e a aceitação das transformações que se encontram inerentes ao processo de envelhecimento foi o que levou a que se sentissem confortáveis na sua própria pessoa. Além disso, ter relações conjugais, uma rede de amigos, saúde física e boa autoestima ajuda, de igual modo, no combate ao stress em indivíduos LGBT mais velhos (Antunes, 2017), sendo que a família aparenta ser a melhor fonte de suporte psicossocial para lidar com as situações de preconceito (Santos et al., 2018) e, desta forma, a aceitação da orientação sexual por parte da família proporciona um processo de envelhecimento mais positivo (Leite, 2014), fundamental para um bom ajustamento mental.

Os fatores anteriormente explicitados têm maior probabilidade de ocorrer no processo de envelhecimento em indivíduos bissexuais, uma vez que estes têm a possibilidade de estabelecer relações afetivas com pessoas de ambos os sexos aumentando a probabilidade de se envolverem em relacionamentos heterossexuais, casarem-se ou 
terem filhos. Consequentemente, as possibilidades de manter redes sociais de apoio em idade avançada seriam mais próximas dos moldes heterossexuais, reduzindo os eventuais riscos de um processo de envelhecimento com redes de apoio frágeis (Barker, Herdt, \& Vries, 2006; Henning, 2017). Com a diminuição destes riscos, a saúde mental destes indivíduos pode ser ligeiramente superior à dos sujeitos gays, sendo que este facto pode ser corroborado pelos resultados do estudo de Pereira, de Vries, Serrano, et al. (2019), conduzido em Portugal e em Espanha, no qual os homens gays em idade avançada relataram níveis mais elevados de sintomas depressivos em comparação com os homens bissexuais mais velhos.

\section{Vírus da Imunodeficiência Humana}

O vírus da imunodeficiência humana (VIH) é uma doença crónica, que pode afetar os indivíduos em qualquer idade (Adekeye, Heiman, Onyeabor, \& Hyacinth, 2012). Este é responsável pela destruição de determinadas células sanguíneas (F. Almeida, 2011) e pode ser transmitido por: via sexual, através de relações sexuais desprotegidas; após a utilização de material contaminado, por partilha de agulhas ou seringas; ou, através do contágio de mãe para filho (Direção Geral da Saúde, 2019).

Alguns dos efeitos do VIH no sistema imunológico ocorrem logo no início da infeção e podem ser persistentes no tempo (Derdeyn \& Silvestri, 2005; Davis, 2013), tornando as pessoas mais suscetíveis a outras infeções (Lopes \& Fraga, 1998) e exacerbando diversas doenças já associadas à pessoa mais velha, como doenças cardiovasculares, diabetes ou osteoporose (Mills, Bärnighausen, \& Negin, 2012). Como tal, o impacto do diagnóstico de VIH pode causar mudanças em diversos aspetos da vida dos indivíduos (Okuno et al., 2014), exigindo muito ao doente, tanto a nível físico, como psicológico, social e ambiental (Moskowitz, Hult, Bussolari, \& Acree, 2009), tendo o indivíduo de se adaptar à sua nova condição de saúde (F. Almeida, 2011).

A prevenção e o controlo desta doença têm sido um grande desafio para a área da saúde, uma vez que não há cura para a mesma e a sua propagação é persistente (Okuno et al., 2014). Contudo, o VIH pode ser controlado por meio de terapia farmacológica, apesar de este acarretar consigo inúmeros efeitos adversos que podem comprometer significativamente a qualidade de vida dos indivíduos (Kemppainen et al., 2012).

O VIH pode, assim, dar origem a inúmeras consequências psicossociais, profissionais, familiares e/ou orgânicas, sendo constantemente associada a situações de preconceito e discriminação (Nascimento, Albuquerque, Marinelli, Campelo, \& Santos, 
2017). Um estudo de Nascimento et al. (2017) demonstrou que a dificuldade de superação e aceitação do diagnóstico de VIH se encontra relacionado com o estigma acerca desta mesma doença. Deste modo, a aceitação deste diagnóstico pode depender da perceção da condição de se ser um indivíduo VIH+ e parece simbolizar uma oportunidade de reflexão sobre a vida, em relação a si próprio e aos outros (Teixeira \& Silva, 2008), sendo que pessoas diagnosticadas há mais tempo, embora assumam o diagnóstico de VIH como um problema, encaram a doença como uma oportunidade de aprendizagem, com esperanças de que encontrem a cura e adaptando a sua vida de acordo com a doença (Okuno et al., 2014).

\subsection{VIH, Processo de Envelhecimento e Orientação Sexual}

Os primeiros casos de infeção pelo VIH foram diagnosticados, em 1981 (Chaves, Duarte, Ferreira, \& Dionísio, 2016), na comunidade jovem homossexual da Califórnia e Nova Iorque. Em Portugal, o primeiro caso de VIH foi diagnosticado em 1983 (Departamento de Doenças Infecciosas, 2013). Estes indivíduos apresentavam infeções e cancros raros, resultantes de uma imunodeficiência de causa desconhecida (André, 2005, citado por F. Almeida, 2011). Como os primeiros casos foram diagnosticados em homens homossexuais, a sociedade começou a denominar esta doença como "cancro gay" ou "peste gay" (Garrafa, Machado Godoi, \& Pereira Soares, 2012; Gross \& Pinhal de Carlos, 2015; Terto Jr., 2002), associando o diagnóstico de VIH como uma consequência de condutas sexuais desviantes (K. Sousa, 2016).

Não existe, ainda, uma cura para o VIH, contudo nas últimas décadas, com as melhorias ao nível do tratamento médico, ocorreu uma melhoria da qualidade de vida e longevidade dos indivíduos VIH+ (F. Almeida, 2011; Davis, 2013). Além disso, assiste-se hoje a uma crescente expectativa de vida, a melhoria das condições de saúde, mudanças nos padrões de saúde e de doença, a redução das taxas de mortalidade e à diminuição das taxas de natalidade (Figueiredo \& Provinciali, n.d.). Como tal, em pouco tempo, o número de indivíduos mais velhos infetados com VIH tem vindo a aumentar de modo significativo (Mills et al., 2012), sendo que a epidemia de VIH afeta desproporcionalmente os indivíduos mais velhos LGBT (Services \& Advocacy for Gay, Lesbian, Bisexual \& Transgender Elders, n.d.), nomeadamente os homens gays e bissexuais (Davis, 2013).

O processo de envelhecimento associado ao diagnóstico de VIH pode ser marcado por sentimentos negativos que advém do preconceito da sociedade para com os portadores de VIH (Nascimento et al., 2017). Desta forma, os indivíduos mais velhos diagnosticados com VIH enfrentam uma série de desafios clínicos acrescidos devido ao facto de a sua recuperação imunológica ser mais lenta, em comparação com a população 
mais jovem (Mills et al., 2012). Além disso, enfrentam o fardo adicional de pertencerem a um segundo grupo minoritário estigmatizado (Lyons et al., 2012). Como tal, o suporte da rede de apoio social é fundamental na vida da pessoa afetada por VIH (G. Andrade \& Vaitsman, 2002), sendo que Wohl et al. (2013) sugerem que o suporte social pode ter um efeito moderador no estigma relacionado com o VIH.

Como é possível verificar os homens gays e bissexuais mais velhos com diagnóstico de VIH sofrem de situações extremas de preconceito e estigma que podem levar a défices ao nível da saúde mental. Como tal, a seguir, apresentam-se algumas das consequências que podem afetar estes indivíduos.

\section{Saúde Mental na Comunidade LGBT com VIH}

Os indivíduos pertencentes à comunidade LGBT estão sujeitos a preconceitos, discriminação, estereótipos, stress e exclusão social, assim como a violência e, muitas vezes, internalizam um sentimento de vergonha no que concerne a sua orientação sexual (Meyer, 2003; Hatzenbuehler, Nolen-Hoeksema, \& Erickson, 2008; Santos et al., 2018). Além disso, as pessoas não-heterossexuais apresentam-se como tendo menos poder em comparação com sujeitos heterossexuais, no sentido de terem menos acessos a recursos, menor influência sobre os outros e menor controlo sobre o seu próprio destino (Link \& Phelan, 2001). Como tal, podem experienciar níveis mais deficitários de saúde mental quando comparados com a população heterossexual (King et al., 2008).

Num estudo de Meyer (1995) os resultados indicaram que o stress de minorias prevê sofrimento psicológico para homens gays, afetando a sua saúde mental. Um estudo realizado na Índia foi ao encontro desta suposição, vinculando o stress psicológico associado à homofobia com perturbações ao nível da saúde mental (Tomori et al., 2016). Desta maneira, o stress crónico pode ser responsável por respostas desadaptativas que podem estar na origem de várias perturbações, das quais se destacam a ansiedade e a depressão. Tal ocorre devido à exposição prolongada, de forma sustentada, ao stress (Tafet, 2019).

Em situações de stress crónico, isto é, quando os fatores de stress afetam o indivíduo de maneira sustentada e prolongada, a ansiedade é uma experiência emocional frequente e não podemos esperar que se resolva nem fácil nem rapidamente, mas sim que se mantenha de forma crónica, assim como os fatores de stress que a provocam (Tafet, 2019). Neste sentido, Pereira e Leal (2012) referem que “os gays, as lésbicas e os bissexuais representam uma minoria sexual. Como tal, enfrentam tanta discriminação, 
estigmatização e violência que é apenas natural que, como resultado, lhes ocorram elevados níveis de stress e ansiedade" (pp. 107-108), o que pode ser corroborado no estudo de Sandfort, de Graaf, Bijl, e Schnabel (2001), no qual homens com parceiros sexuais do mesmo género demonstraram maior probabilidade de serem diagnosticados com perturbação de ansiedade social ao longo da vida.

Ademais, os indivíduos homossexuais, por vezes, interiorizam a violência que lhes é dirigida, reprimindo-a ou deslocando essa violência para os outros ou para si mesmo, dando origem a sintomas depressivos e atitudes autodestrutivas (Toledo \& Pinafi, 2012), sendo que estes homens têm uma probabilidade três vezes superior de sofrer de depressão quando comparados com a restante população adulta (Cox, 2012).

Os diversos estudos demonstram, assim, que indivíduos pertencentes a uma minoria sexual têm maiores probabilidades de desenvolver uma perturbação mental, particularmente baixa autoestima, depressão e ansiedade (Antunes, 2017; Cochran, 2001; Grov, Golub, Parsons, Brennan, \& Karpiak, 2010; Hatzenbuehler et al., 2008; K. Sousa, 2016). As potenciais causas destas perturbações podem estar associadas com problemas de relacionamento, aceitação de si próprio, experienciar homofobia e discriminação (Cox, 2012).

Acrescentando a variável idade, pode verificar-se nos homens gays e bissexuais mais velhos uma sobreposição de dois estigmas, associados com a sua orientação sexual e com a sua idade (Antunes, 2017). Além disso, estes sujeitos podem ter as suas redes de suporte numa situação deficitária, uma vez que para muitos homens gays e bissexuais as relações com a família, amigos e vizinhos se tornam frágeis ou, até mesmo, inexistentes, devido à quebra de vínculos afetivos entre os mesmos (Crenitte et al., 2019). Como tal, há maior probabilidade de estes sofrerem de sintomas de depressão (Antunes, 2017), uma vez que a solidão e o isolamento social podem ter impacto direto na saúde dos indivíduos mais velhos, interferindo com o controlo de sintomas depressivos e/ou ansiosos (Yarns, Abrams, Meeks, \& Sewell, 2016).

Como referido previamente, a sociedade tem tendência para associar a comunidade LGBT ao diagnóstico de VIH (Santos et al., 2018). Este estigma afeta negativamente a saúde mental dos indivíduos (Logie \& Gadalla, 2009), encontrando-se associado a níveis mais elevados de sintomas depressivos (F. Almeida, 2011; Gore-Felton \& Koopman, 2008; Logie et al., 2012), de isolamento e discriminação (Gore-Felton \& Koopman, 2008).

Num estudo de Larios, Davis, Gallo, Heinrich e Talavera (2009), foi encontrada uma associação entre o estigma de VIH com a depressão e a autoestima. Associação essa 
corroborada mais tarde com o estudo de Wohl et al. (2013) onde foi apresentada uma associação entre o estigma relacionado com homens gays e a depressão, assim como o estigma associado ao VIH e a depressão. No estudo de Tomori et al. (2016) os homens que fazem sexo com homens, com diagnóstico de VIH, cientes da sua infeção apresentaram, também, maior probabilidade de sofrer de sintomas depressivos em comparação com os seus pares não infetados pela doença.

Deste modo, experienciar estigma relacionado com o VIH encontra-se associado com níveis mais elevados de depressão, mas também com níveis reduzidos de suporte social (Rueda et al., 2016), sendo que estes sujeitos preenchem os critérios para perturbação de ansiedade generalizada, a uma taxa de quase oito vezes maior quando comparadas com a população em geral (Bing, et al., 2001).

\section{Referências Bibliográficas}

Adekeye, O. A., Heiman, H. J., Onyeabor, O. S., \& Hyacinth, H. I. (2012). The new invincibles: HIV screening among older adults in the U.S. PLOS ONE, 7(8), 1-9. https://doi.org/10.1371/journal.pone.0043618

Allen, A. J., Leonard, H., \& Swedo, S. E. (1995). Current knowledge of medications for the treatment of childhood anxiety disorders. Journal of the American Academy of Child and Adolescent Psychiatry, 34(8), 976-986. https://doi.org/10.1097/00004583199508000-00007

Almeida, F. A. (2011). VIH/SIDA: Narrativas de homens homossexuais com mais de 50 anos. [Dissertação de Mestrado, Universidade de Aveiro].

Andrade, G. R., \& Vaitsman, J. (2002). Apoio social e redes: Conectando solidariedade e saúde. Ciência \& Saúde Coletiva, 7(4), 925-934. https://doi.org/10.1590/s141381232002000400023

Andrade, H. A., Silva, S. K., \& Santos, M. I. (2010). AIDS em idosos: Vivências dos doentes. Escola Anna Nery, 14(4), 712-719. https://doi.org/10.1590/s141481452010000400009

Antunes, P. P. (2017). Homens homossexuais, envelhecimento e homofobia internalizada. Revista Kairós: Gerontologia, 20(1), 311-335. https://doi.org/10.23925/2176901x.2017v20i1p311-335

Araújo, L. F. (2016). Aspectos psicossociais da velhice LGBT. Psicologia Em Estudo, 21(2), 359-361. https://doi.org/10.4025/psicolestud.v21i2.28739

Araújo, L. F., Silva, R. J., \& Santos, J. V. (2017). Resiliência e velhice: Um estudo comparativo entre idosos de diferentes níveis socioeconômicos. Revista Kairós: Gerontologia, 20(1), 389-407. https://doi.org/10.23925/2176-901x.2017v20i1p389- 
407

American Psychiatric Association. (2014). Manual Diagnóstico e Estatístico de Perturbações Mentais - DSM-5 (Quinta Ed.). Lisboa: Climepsi Editores.

American Psychological Association. (2020). Building your resilience. Retrieved from https://www.apa.org/topics/resilience

Barker, J. C., Herdt, G., \& Vries, B. (2006). Social support in the lives of lesbians and gay men at midlife and later. Sexuality Research and Social Policy, 3(2), 1-23. https://doi.org/10.1525/srsp.2006.3.2.1

Baumeister, R. F., Campbell, J. D., Krueger, J. I., \& Vohs, K. D. (2003). Does high selfesteem cause better performance, interpersonal success, happiness, or healthier lifestyles? Psychological Science in the Public Interest, 4(1), 1-44. https://doi.org/10.1111/1529-1006.01431

Bilodeau, B. L., \& Renn, K. A. (2005). Analysis of LGBT identity development models and implications for practice. New Directions for Student Services, 2005(111), 25-39. https://doi.org/10.1002/ss.171

Branden, N. (2009). A importância da auto-estima. In Como aumentar sua auto-estima (pp. 10-15). Sextante.

Campos, R. C., \& Gonçalves, B. (2011). The portuguese version of the Beck Depression Inventory-II (BDI-II): Preliminary psychometric data with two nonclinical samples. European Journal of Psychological Assessment, 27(4), 258-264. https://doi.org/10.1027/1015-5759/aoooo72

Carvalho, A. I. (2012). Sintomatologia depressiva e estratégias de coping em adultos em idade laboral. [Dissertação de Mestrado, Universidade da Beira Interior]. Retrieved from http://hdl.handle.net/10400.6/2683

Carvalho, S., Jara, J. M., \& Cunha, I. B. (2017). A depressão é uma doença que se trata. Associação De Apoio Aos Doentes Depressivos E Bipolares, 1-10. Retrieved from https://www.adeb.pt/files/upload/guias/a-depressao-e-uma-doenca-que-setrata.pdf

Chaves, C., Duarte, J., Ferreira, M., \& Dionísio, R. (2016). Avaliação da prática da educação para a saúde na área da SIDA nos cuidados de saúde primários. Millenium Journal of Education, Technologies and Health, 15(38), 201-221.

Chincalece, L. F. (2009). Alexitimia e psicopatologia: Estudo exploratório em alunos de psicologia. [Dissertação de Mestrado, ISPA - Instituto Superior de Psicologia Aplicada]. Retrieved from http://hdl.handle.net/10400.12/4428

Cochran, S. D. (2001). Emerging issues in research on lesbians' and gay men's mental health: Does sexual orientation really matter? American Psychologist, 56(11), 931947. https://doi.org/10.1037/0003-066X.56.11.931 
Correia, S. A. (2018). Resiliência em profissionais de saúde. [Projeto de Mestrado, Instituto Politécnico de Coimbra]. Retrieved from https://comum.rcaap.pt/bitstream/10400.26/25733/1/Resiliência em PS_completo.pdf

Costa, C. G., Pereira, M., Oliveira, J. M., \& Nogueira, C. (2010). Imagens sociais das pessoas LGBT. Estudo Sobre a Discriminação Em Função Da Orientação Sexual e Da Identidade de Género, 93-147.

Cox, S. (2012). Living on the edge: Gay men, depression and risk-taking behaviors. The Medius Institute for Gay Men's Health, 1-43.

Cremers-Laurent, A. J. (2015). A importância da autoestima para um desenvolvimento harmonioso: "Sinto-me amada e capaz, vou alcançar as estrelas!" [Relatório de Estágio, Universidade do Algarve]. Retrieved from https://core.ac.uk/download/pdf/61527301.pdf

Crenitte, M. R., Miguel, D. F., \& Filho, W. J. (2019). Abordagem das particularidades da velhice de lésbicas, gays, bissexuais e transgêneros. Geriatrics, Gerontology and Aging, 13(1), 50-56. https://doi.org/10.5327/z2447-211520191800057

Davis, J. A. (2013). HIV and the LGBT community: A medical update. Journal of Gay and Lesbian Mental Health, 17(1), 64-79. https://doi.org/10.1080/19359705.2013.737738

Decreto Lei n.o 9/201o de 31 de maio da Assembleia da República., Diário da República n.o 105/2010, Série I (2010).

Decreto Lei n.o 99/2003 de 27 de agosto da Assembleia da República., Diário da República n.o 197/2003, Série I-A (2003).

Departamento de Doenças Infecciosas do INSA. Unidade de Referência e Vigilância Laboratorial Epidemiológica. Núcleo de Vigilância Laboratorial de Doenças (2013). Infeção VIH/SIDA: A situação em Portugal a 31 de dezembro de 2012. In 144. Instituto Nacional de Saúde Doutor Ricardo Jorge.

Derdeyn, C. A., \& Silvestri, G. (2005). Viral and host factors in the pathogenesis of HIV infection. Current Opinion in Immunology, 17, 366-373. https://doi.org/10.1016/j.coi.2005.06.001

Direção Geral da Saúde (2019). Temas da saúde: Vírus da imunodeficiência humana (VIH). Retrieved from https://www.sns24.gov.pt/tema/doencas-infecciosas/vih/

Duarte, M. J. (n.d.). Diversidade sexual e saúde mental. VI Congresso Internacional de Estudos Sobre a Diversidade Sexual e de Género Da ABEH, 1-15.

Duarte, M. J. (2014). Diversidade sexual, políticas públicas e direitos humanos: Saúde e cidadania LGBT em cena. Temporalis, (27), 77-98. https://doi.org/10.22422/22381856.2014v14n27p77-98 
Dutton, K. A., \& Brown, J. D. (1997). Global self-esteem and specific self-views as determinants of people's reactions to success and failure. Journal of Personality and Social Psychology, 73(1), 139-148. https://doi.org/10.1037/o022-3514.73.1.139

Feder, D. J. (2019). Resiliência: Como a mente supera as adversidades (A. C. Caldas, Ed.). Correio da Manhã.

Figueiredo, M. A., \& Provinciali, R. M. (n.d.). HIV/AIDS em pessoas idosas. Vulnerabilidade, convívio e enfrentamento. VII Congresso Virtual HIV/AIDS, 1-8. https://doi.org/10.1017/CBO9781107415324.004

Filho, J. A. (2014). A resiliência e seus desdobramentos: A resiliência familiar. Psicologia.Pt, $1-15$. $\quad$ Retrieved from http://www.psicologia.pt/artigos/ver_artigo.php?a-resiliencia-e-seusdesdobramentos-a-resiliencia-familiar\&codigo $=\mathrm{Ao806}$

Filho, N. D., Coelho, M. T., \& Peres, M. F. (1999). O conceito de saúde mental. Revista USP, (43), 100-125. https://doi.org/10.116o6/issn.2316-9036.voi43p100-125

Garrafa, V., Machado Godoi, A. M., \& Pereira Soares, S. (2012). HIV/AIDS and the principle of non-discrimination and non-stigmatization. Revista Latino-americana de Bioética, 12(2), 118-123. https://doi.org/10.18359/rlbi.965

Gonçalves, B., \& Fagulha, T. (2004). The portuguese version of the Center for Epidemiologic Studies Depression scale (CES-D). European Journal of Psychological Assessment, 20(4), 1-27. https://doi.org/10.1027/1015-5759.20.4.339

Gore-Felton, C., \& Koopman, C. (2008). Behavioral mediation of the relationship between psychosocial factors and HIV disease progression. Psychosomatic Medicine, 70, 569574. https://doi.org/10.1097/PSY.obo13e318177353e

Gross, J., \& Pinhal de Carlos, P. (2015). Da construção da sexualidade aos direitos LGBT: Uma lenta conquista. Revista Direito e Política, 10(2), 747-761. https://doi.org/10.14210/rdp.v10n2.p747-761

Grov, C., Golub, S. A., Parsons, J. T., Brennan, M., \& Karpiak, S. E. (2010). Loneliness and HIV-related stigma explain depression among older HIV-positive adults. AIDS Care Psychological and Socio-Medical Aspects of AIDS/HIV, 22(5), 630-639. https://doi.org/10.1080/09540120903280901

Guerreiro, D. P. (2011). Necessidade psicológica de auto-estima/auto-crítica: Relação com bem-estar e distress psicológico [Dissertação de Mestrado, Universidade de Lisboa]. $\quad$ Retrieved from http://repositorio.ul.pt/bitstream/10451/496o/1/ulfpieo39658_tm.pdf

Guilhardi, H. J. (2002). Auto-estima, autoconfiança e responsabilidade. Instituto de Terapia Por Contingências de Reforçamento, 1-29.

Guimarães, A. F. (2009). O desafio histórico de “tornar-se um homem homossexual”: Um 
exercício de construção de identidades. Temas Em Psicologia, 17(2), 553-567.

Guimarães, J. V. (2012). Autoconceito, autoestima e comportamentos desviantes em adolescentes. [Dissertação de Mestrado, ISPA - Instituto Superior de Psicologia Aplicada]. Retrieved from http://widgets.ebscohost.com/prod/customerspecific/nsoo0290/authentication/ind ex.php?url=https\%253A\%252F\%252Fsearch.ebscohost.com\%252Flogin.aspx\%253F direct\%253Dtrue\%2526AuthType\%253Dip\%252Ccookie\%252Cshib\%252Cuid\%2526 db\%253Dedsrca\%2526AN\%253Drcaap.com.isp

Hatzenbuehler, M. L., Nolen-Hoeksema, S., \& Erickson, S. J. (2008). Minority stress predictors of HIV risk behavior, substance use, and depressive symptoms: Results from a prospective study of bereaved gay men. Health Psychology, 27(4), 455-462. https://doi.org/10.1037/0278-6133.27.4.455

Henning, C. E. (2017). Gerontologia LGBT: Velhice, gênero, sexualidade e a constituição dos “idosos LGBT.” Horizontes Antropológicos, 23(47), 283-323. https://doi.org/10.1590/s0104-71832017000100010

Herek, G. M. (2007). Confronting sexual stigma and prejudice: Theory and practice. Journal of Social Issues, 63(4), 905-925. https://doi.org/10.1111/j.15404560.2007.00544.x

Herrman, H., Stewart, D. E., Diaz-Granados, N., Berger, E. L., Jackson, B., \& Yuen, T. (2011). What is resilience? Canadian Journal of Psychiatry, 56(5), 258-265. https://doi.org/10.1177/070674371105600504

Hutz, C. S., \& Zanon, C. (2011). Revisão da adaptação, validação e normatização da Escala de Autoestima de Rosenberg. Avaliação Psicológica, 10(1), 41-49.

Joseph, S., \& Linley, P. A. (2006). Growth following adversity: Theoretical perspectives and implications for clinical practice. Clinical Psychology Review, 26, 1041-1053. https://doi.org/10.1016/j.cpr.2005.12.006

Kemppainen, J., Bormann, J. E., Shively, M., Kelly, A., Becker, S., Bone, P., ... Gifford, A. L. (2012). Living with HIV: Responses to a mantram intervention using the critical incident research method. Journal of Alternative and Complementary Medicine, 18(1), 76-82. https://doi.org/10.1089/acm.2009.0489

King, M., Semlyen, J., Tai, S. S., Killaspy, H., Osborn, D., Popelyuk, D., \& Nazareth, I. (2008). A systematic review of mental disorder, suicide, and deliberate self-harm in lesbian, gay and bisexual people. BMC Psychiatry, 8(70), 1-17. https://doi.org/10.1186/1471-244X-8-70

Larios, S. E., Davis, J. N., Gallo, L. C., Heinrich, J., \& Talavera, G. (2009). Concerns about stigma, social support and quality of life in low-income HIV-positive hispanics. Ethricity \& Disease, 19, 65-70. 
Leite, I. M. (2014). Envelhecimento homossexual: preocupações, anseios e preconceitos sentidos. [Dissertação de Mestrado, ISSP - Instituto Superior de Serviço Social do Porto]. http://hdl.handle.net/10400.26/6498

Lima, P. V. (2013). Homossexualidade na terceira idade: Revisão de literatura. Revista Eletrônica Gestão \& Saúde, 4(2), 2289-2299.

Link, B. G., \& Phelan, J. C. (2001). Conceptualizing stigma. Annual Review of Sociology, 27, 363-385. https://doi.org/10.1146/annurev.soc.27.1.363

Logie, C., \& Gadalla, T. M. (2009). Meta-analysis of health and demographic correlates of stigma towards people living with HIV. AIDS Care - Psychological and SocioMedical Aspects of AIDS/HIV, 21(6), 742-753. https://doi.org/10.1080/09540120802511877

Logie, C. H., Newman, P. A., Chakrapani, V., \& Shunmugam, M. (2012). Adapting the minority stress model: Associations between gender non-conformity stigma, HIVrelated stigma and depression among men who have sex with men in South India. Social Science and Medicine, 74, 1261-1268. https://doi.org/10.1016/j.socscimed.2012.01.008

Lopes, M. V., \& Fraga, M. N. (1998). Pessoas vivendo com HIV: Estresse e suas formas de enfrentamento. Revista Latino-Americana de Enfermagem, 6(4), 75-81. https://doi.org/10.1590/s0104-11691998000400010

Lyons, A., Pitts, M., \& Grierson, J. (2012). Exploring the psychological impact of HIV: Health comparisons of older australian HIV-positive and HIV-negative gay men. AIDS and Behavior, 16, 2340-2349. https://doi.org/10.1007/s10461-012-0252-8

Marques, E. T. (2003). Da loucura à doença mental, da doença mental à inimputabilidade. [Dissertação de Mestrado, ISPA - Instituto Superior de Psicologia Aplicada]. http://hdl.handle.net/10400.12/644

Masten, A. S. (2014). Global perspectives on resilience in children and youth. Child Development, 85(1), 6-20. https://doi.org/10.1111/cdev.12205

Matias, D. (2007). Psicologia e orientação sexual: Realidades em transformação. Análise Psicológica, 25(1), 149-152. https://doi.org/10.14417/ap.436

Meyer, I. H. (1995). Minority stress and mental health in gay men. Journal of Health and Social Behavior, 36(1), 38-56. https://doi.org/10.2307/2137286

Meyer, I. H. (2003). Prejudice, social stress, and mental health in lesbian, gay, and bisexual populations: Conceptual issues and research evidence. Psychological Bulletin, 129(5), 674-697. https://doi.org/10.1037/0033-2909.129.5.674

Mills, E. J., Bärnighausen, T., \& Negin, J. (2012). HIV and aging - Preparing for the challenges ahead. New England Journal of Medicine, 366(14), 1270-1273. https://doi.org/10.1056/NEJMp1113643 
Moreno, E. S., \& Roda, A. B. (2003). Social psychology of mental health: The social structure and personality perspective. The Spanish Journal of Psychology, 6(1), 3-11. https://doi.org/10.5209/rev_SJOP.2003.v6.n1.30453

Moskowitz, J. T., Hult, J. R., Bussolari, C., \& Acree, M. (2009). What works in coping with HIV? A meta-analysis with implications for coping with serious illness. Psychological Bulletin, 135(1), 121-141. https://doi.org/10.1037/a0014210

Mota, M. P. (2009). Homossexualidade e envelhecimento: Algumas reflexões no campo da experiência. SINAIS - Revista Eletrônica, 1(06), 26-51. https://doi.org/10.25067/s.v1io6.2752

Nascimento, E. K., Albuquerque, L. P., Marinelli, N. P., Campelo, M. N., \& Santos, F. J. (2017). História de vida de idosos com HIV/AIDS. Revista de Enfermagem UFPE, 11(4), 1716-1724. https://doi.org/10.5205/reuol.9763-85423-1-SM.1104201721

Okuno, M. F., Gomes, A. C., Meazzini, L., Scherrer Júnior, G., Belasco Junior, D., \& Belasco, A. G. (2014). Qualidade de vida de pacientes idosos vivendo com HIV/AIDS. Cadernos de Saude Publica, 30(7), 1551-1559. https://doi.org/10.1590/0102311 Xooo95613

Pais-Ribeiro, J. L., Honrado, A., \& Leal, I. (2004). Contribuição para o estudo da adaptação portuguesa das Escalas de Ansiedade, Depressão e Stress (EADS) de 21 itens de Lovibond e Lovibond. Psicologia, Saúde e Doenças, 5(2), 229-239.

Panter-Brick, C., \& Leckman, J. F. (2013). Editorial commentary: Resilience in child development - Interconnected pathways to wellbeing. Journal of Child Psychology and Psychiatry, 54(4), 333-336. https://doi.org/10.1111/jcpp.12057

Pereira, H., de Vries, B., Serrano, J. P., Afonso, R. M., Esgalhado, G., \& Monteiro, S. (2019). Depression and quality of life in older gay and bisexual men in Spain and Portugal. International Journal of Aging and Human Development, 1-16. https://doi.org/10.1177/o091415019864600

Pereira, H., \& Leal, I. (2012). A homofobia internalizada e os comportamentos para a saúde numa amostra de homens homossexuais. Análise Psicológica, 20(1), 107-113. https://doi.org/10.14417/ap.287

Pereira, H., \& Leal, I. P. (2005). A identidade (homo)sexual e os seus determinantes: Implicações para a saúde. Análise Psicológica, 23(3), 315-322. https://doi.org/10.14417/ap.95

Pereira, H., Serrano, J. P., de Vries, B., Esgalhado, G., Afonso, R. M., \& Monteiro, S. (2017). Aging perceptions in older gay and bisexual men in Portugal: A qualitative study. International Journal of Aging and Human Development, 1-28. https://doi.org/10.1177/o091415017720889

Pesce, R. P., Assis, S. G., Santos, N., \& Oliveira, R. de V. C. (2004). Risco e proteção: Em 
busca de um equilíbrio promotor de resiliência. Psicologia: Teoria e Pesquisa, 20(2), 135-143. https://doi.org/10.1590/s0102-37722004000200006

Pinheiro, D. P. (2004). A resiliência em discussão. Psicologia Em Estudo, 9(1), 67-75. https://doi.org/10.1590/s1413-73722004000100009

Pinto, J. C., Martins, P., Pinheiro, T. B., \& Oliveira, A. C. (2015). Ansiedade, depressão e stresse: Um estudo com jovens adultos e adultos portugueses. Psicologia, Saúde \& Doenças, 16(2), 148-163. https://doi.org/10.15309/15psd160202

Poletto, M., \& Koller, S. H. (2008). Contextos ecológicos: Promotores de resiliência, fatores de risco e de proteção. Estudos de Psicologia (Campinas), 25(3), 405-416. https://doi.org/10.1590/s0103-166x2008000300009

Pope, M., Wierzalis, E. A., Barret, B., \& Rankins, M. (2007). Sexual and intimacy issues for aging gay men. Adultspan Journal, 6(2), 68-82. https://doi.org/10.1002/j.21610029.2007.tbooo33.x

Porto, J. A. (1999). Conceito e diagnóstico. Brazilian Journal of Psychiatry, 21, 6-11.

Ribeiro, J. P., Neto, C., Silva, M., Abrantes, C., Coelho, M., Nunes, J., \& Coelho, V. (2015). Ulterior validação do Questionário de Saúde Geral de Goldberg de 28 itens. Psicologia, Saúde e Doenças, 16(3), 278-285.

Rooke, M. I., \& Pereira-Silva, N. L. (2012). Resiliência familiar e desenvolvimento humano: Análise da produção científica. Psicologia Em Pesquisa, 6(2), 179-186. https://doi.org/10.5327/z1982-12472012000200011

Rueda, S., Mitra, S., Chen, S., Gogolishvili, D., Globerman, J., Chambers, L., ... Rourke, S. B. (2016). Examining the associations between HIV-related stigma and health outcomes in people living with HIV/AIDS: A series of meta-analyses. BMJ Open, 6, 1-15. https://doi.org/10.1136/bmjopen-2016-011453

Sandfort, T. G., de Graaf, R., Bijl, R. V., \& Schnabel, P. (2001). Same-Sex sexual behavior and psychiatric disorders. Archives of General Psychiatry, 58(1), 85-91. https://doi.org/10.1001/archpsyc.58.1.85

Santos, J., Araújo, L., \& Negreiros, F. (2018). Atitudes e estereótipos em relação a velhice LGBT. 29, 57-69.

Santos, J. V., Araújo, L. F., Negreiros, F., \& Cerqueira-Santos, E. (2018). Adoção de crianças por casais homossexuais: As representações sociais. Temas Em Psicologia, 26(1), 139-152. https://doi.org/10.9788/tp2018.1-o6pt

Scartezini, L. G., Rocha, A. C., \& Pires, V. S. (2013). A necessidade de autoestima em Carl Rogers. Revista FAEF, 16, 1-7. Retrieved from http://faef.revista.inf.br/imagens_arquivos/arquivos_destaque/hkNYQZ4GFZuVXw L_2013-5-13-15-59-41.pdf

Schultheisz, T. S., \& Aprile, M. R. (2013). Autoestima, conceitos correlatos e avaliação. 
Revista Equilíbrio Corporal e Saúde, 5(1), 36-48.

Services \& Advocacy for Gay, Lesbian, Bisexual \& Transgender Elders (n.d.). Ten things every LGBT older adult should know about HIV and AIDS. Services \& Advocacy for Gay, Lesbian, Bisexual \& Transgender Elders.

Shively, M. G., \& De Cecco, J. P. (1977). Components of sexual identity. Journal of Homosexuality, 3(1), 41-48. https://doi.org/10.1300/Jo82vo3no1_04

Silva, M. F. (1999). Diferenças de género na depressão e desempenho profissional. [Dissertação de Mestrado, Universidade do Porto]. Retrieved from https://hdl.handle.net/10216/10084

Sordi, A. O., Hauck, S., \& Manfro, G. G. (2011). O conceito de resiliência: Diferentes olhares. Revista Brasileira de Psicoterapia, 13(2), 115-132.

Sousa, K. J. (2016). As diversas manifestações homofóbicas e suas consequências no cotidiano das minorias LGBT. Revista Clóvis Moura de Humanidades, 2(1), 27-44. Retrieved from http://revistacm.uespi.br/revista/index.php/revistaccmuespi/article/view/1

Sousa, M. S. (2015). O papel da autoestima, motivação na construção do ser psicossocial $e$ as problemáticas associadas. [Relatório de Estágio, Unversidade Lusíada de Lisboa]. Retrieved from http://hdl.handle.net/11067/3628

Southwick, S. M., Bonanno, G. A., Masten, A. S., Panter-Brick, C., \& Yehuda, R. (2014). Resilience definitions, theory, and challenges: Interdisciplinary perspectives. European Journal of Psychotraumatology, 5(1), 1-15. https://doi.org/10.3402/ejpt.v5.25338

Souza, M. T., \& Cerveny, C. M. (2006). Resiliência psicológica: Revisão da literatura e análise da produção científica. Interamerican Journal of Psychology, 40(1), 119-126.

Tafet, G. E. (2019). Ansiedade e depressão: As perturbações mais comuns derivadas do stress crónico (A. C. Caldas, Ed.). Correio da Manhã.

Teixeira, M. G., \& Silva, G. A. (2008). A representação do portador do vírus da imunodeficiência humana sobre o tratamento com os anti-retrovirais. Revista $\mathrm{Da}$ Escola de Enfermagem Da USP, 42(4), 729-736.

Terto Jr., V. (2002). Homossexualidade e saúde: Desafios para a terceira década de epidemia de HIV/AIDS. Horizontes Antropológicos, 8(17), 147-158. https://doi.org/10.1590/s0104-71832002000100008

Testa, R. J., Habarth, J., Peta, J., Balsam, K., \& Bockting, W. (2015). Development of the gender minority stress and resilience measure. Psychology of Sexual Orientation and Gender Diversity, 2(1), 65-77. https://doi.org/10.1037/sgdooooo81

Toledo, L. G., \& Pinafi, T. (2012). A clínica psicológica e o público LGBT. Psicologia Clínica, 24(1), 137-163. https://doi.org/10.1590/So103-56652012000100010 
Tomori, C., McFall, A. M., Srikrishnan, A. K., Mehta, S. H., Solomon, S. S., Anand, S., ... Celentano, D. D. (2016). Diverse rates of depression among men who have sex with men (MSM) across India: Insights from a multi-site mixed method study. AIDS and Behavior, 20, 304-316. https://doi.org/10.1007/s10461-015-1201-o

Wohl, A. R., Galvan, F. H., Carlos, J. A., Myers, H. F., Garland, W., Witt, M. D., ... George, S. (2013). A comparison of MSM stigma, HIV stigma and depression in HIV-positive latino and african american men who have sex with men (MSM). AIDS and Behavior, 17, 1454-1464. https://doi.org/10.1007/s10461-012-0385-9

World Health Organization (2018). Mental health: Strengthening our response. Retrieved from https://www.who.int/news-room/fact-sheets/detail/mental-healthstrengthening-our-response

Yarns, B. C., Abrams, J. M., Meeks, T. W., \& Sewell, D. D. (2016). The mental health of older LGBT adults. Current Psychiatry Reports, 18(6), 1-11. https://doi.org/10.1007/s11920-016-0697-y

Yunes, M. A. M. (2003). Psicologia positiva e resiliência: O foco no indivíduo e na família. Psicologia Em Estudo, 8, 75-84. https://doi.org/10.1590/s141373722003000300010 